\title{
الانتهاكات القانونية والشرعية التي تمثلها العلاقات المثلية الشاذة
}

\author{
shel \\ د/ ميادة مصطفى محمد المحروقي \\ أستاذ القانون الجنائي المساعد

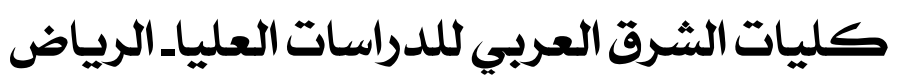




\section{هقدهة}

\section{هوضوع البحث}

توجد غايتان متباينتان للإنسان والطبيعة، فالتناسل هو غاية الطبيعة، والحصول

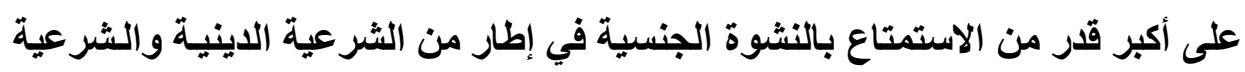

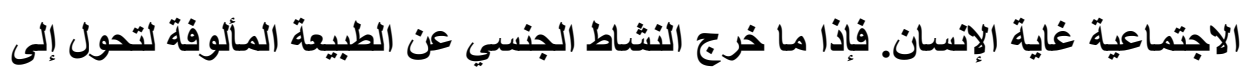

$$
\text { انحراف، أياً كانت الدوافع التي تكمن وراءوان. }
$$

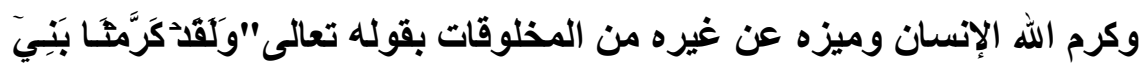

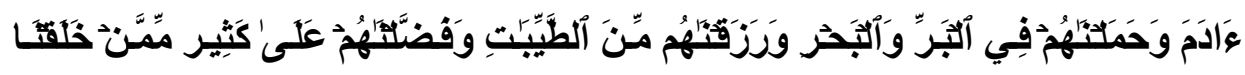

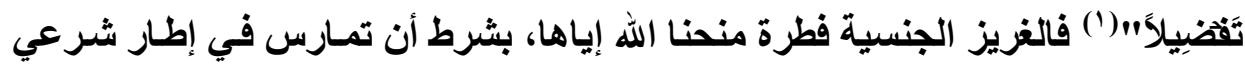

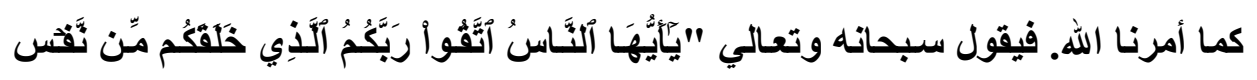

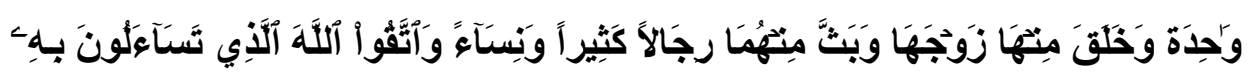

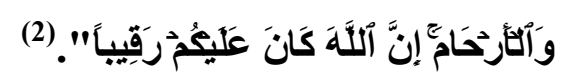

وكان لظهور ممارسات المثلية الثاذة عظيم الأثر على ثقافة الأفراد بـاختلاف

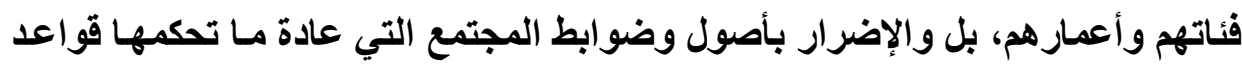

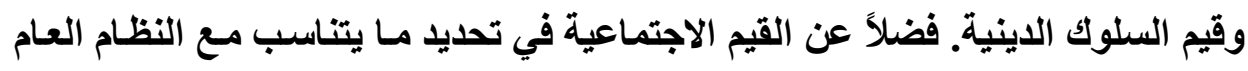

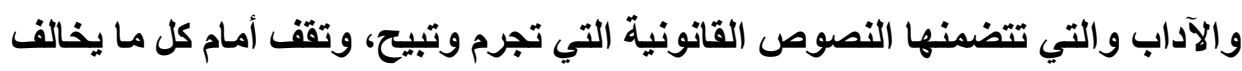

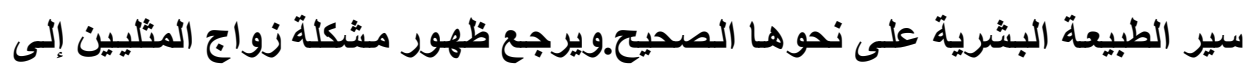
حدوث أول واقعة بثكل رسمي حيث سمح موظف التوثيق في العمودية بتوثيق أول

$$
\begin{aligned}
& \text { (1) سورة الإسراء، الأية رقم · V. }
\end{aligned}
$$

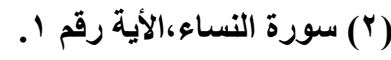




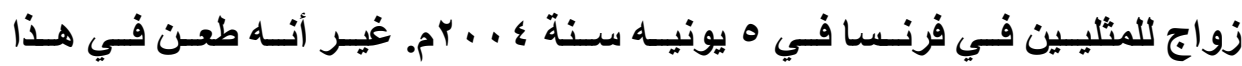

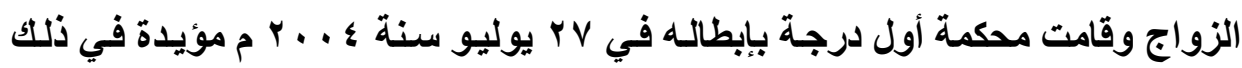

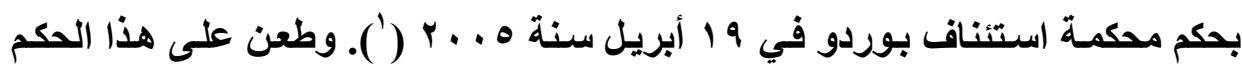

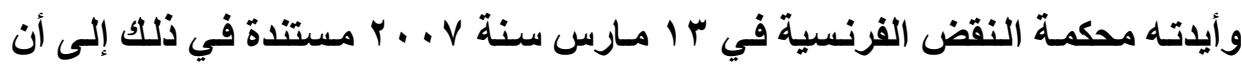

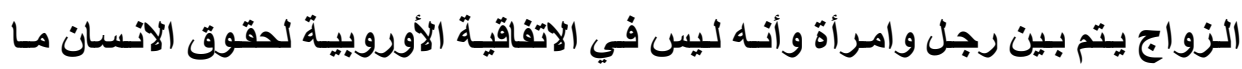

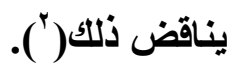
ومنذ ذلك الحين ظهرت المنـاداة بحقوق المثليين والاعتراف بهم كغيرهم من الأثـخاص الطبيعيين. وهو مـا يتــافى مـع الطبيعـة الإنساتية والقيم والأعراف وسير الحياة على الفطرة التي خلق الله بها الإنسان. فباتت الدول في تحد دائم لهذه الظاهرة التي تعدم أصل الحيـاة وتهـم بنـاء المجتمع السوي. ومـا ترتبـه من انتهاكـات تصيب الشخص قبل أن تصيب المجتمع.

مشكلة البحث وتساؤلاته

أصبحت العلاقات المثلية الشاذة تأخذ طابعًا علنياً، ولعل من أبرز صورها في الوقت الراهن ظهور المطالبـات بتقتين زواج المثليين وإثبـات حقهم في التبنـي، بـل وتزايد الدعوات إلى الاعتراف بحقوقهم ومطالبة الدول بحمايتهم بل تعديل أنظمتها بمـا

(1) RTD. civ. 2005. 574, obs. J. Hauser

(2)Jean-Pierre Marguénaud, Le mariage entre personnes du même «sexe» renvoyé aux calendes grecques ?RTD.Civ. 2007, p.286Civ. $1^{\text {re }}, 13$ mars 2007, D. 2007.1389, rapp. G. Huyette et note E. Agostini ; cette revue, infra 315, obs. J. Hauser ; AJ fam. 2007.227, obs. F. Chénedé ; CEDH 28 nov. 2006, décis. d'irrecevabilité R. et F. c/ Royaume-Uni et Parry c/ Royaume-Uni) 
يتناسب مـع تلك العلاقـات الشاذة.وهو مـا ترتب عليه تجـاوز لكل الثوابت الاجتماعية والأخلاقية.

ولعل ما يزيد الأمر تعقيداً هو تحول دور المثليين من مرحلة الدفاع إلى مرحلة الهجوم، وتحديهم للقوانين والثرائع في ظل غطاء من الدعم الدولي لهم، وخير دليل على ذلك ما تنادي به المنظمات واللجان الحقوقية، كالقرار الصادر عن اللجنة الإفريقية لحقوق الإنسان والشعوب في مـايو \& 1 ـ بم، والذي تضمن وضـع حد لكافة أعمـال العنف والاعتداء الرسمية منها وغير الرسمية، بمـا في ذلك إصدار وتفعيل القوانين اللازمة، وحظر معاقبة كافة أشكال العنف الذي يستهدف الأفراد على أسـاس الميول الجنسية والهوية النوعية المفترضة منها والفعلية، وضمان التحقيق الوافي والملاحقة الحثيثـة للجنـاه، فضلاً عن تطوير الاجـراءات القضائية اللازمسة للاستجابة لحاجـات الضحايا.(') ونتزايد تلك المطالبات اليوم تلو الآخر، وأصبحت الدول الرافضة للعلاقـات المثلية الشاذة في صراع مع الثواذ جنسياً إلى جاتب المنظمات التي تدافع عن حقوقهم بل تطالب بسن قوانين لحمايتهم.

وعليه فسوف يجيب البحث عن التساؤلات التالية: ماذا يقصد بالعلاقات الجنسية

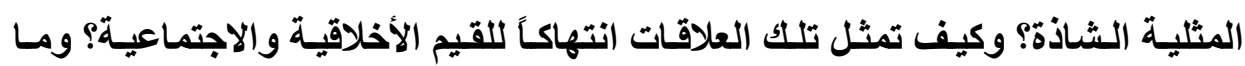

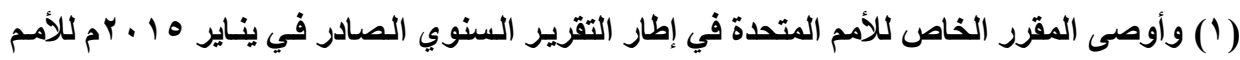

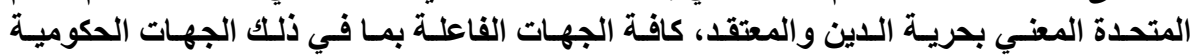

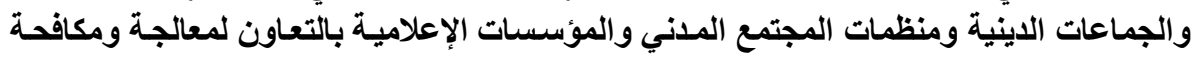

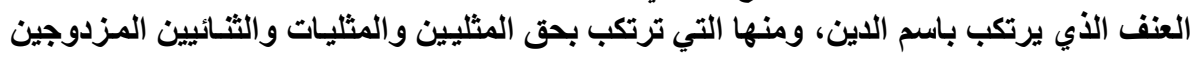

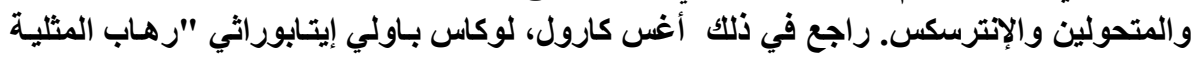

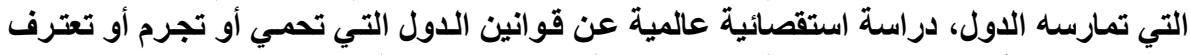

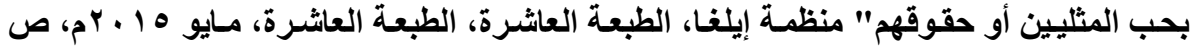


الموقف الذي تتخذه الدول بين مؤيد ومعارض لتلك العلاقات؟ ومـا الآثار المترتبة على تلكت العلاقـات الشـاذة بالنسبة للفرد والمجتمع؟ ومـا الحلـول المناسبة للحد مـن هذه

الظاهرة؟

\section{أهداف البحث}

يهرف البحث إلى تحقيق الأهداف التالية:

1 - بيان المقصود بالعلاقات المثلية الثاذة وانتهاكها لقواعد الدين والأخلاق.

r - بيان رأي الدول ما بين مؤيد ومعارض لممارسات الجنسية المثلية الثـاذة.

r- إبرازأهم الانتهاكات القانونية التي ترتبها العلاقات المثلية الثاذة.

ع - توضيح الانتهاكات الشرعية التي ترتبها العلاقات المثلية الثاذة .

ه- عرض لأهم الآثار التي تصيب الفرد والمجتمع من جراء ارتكاب تلك الأفعال.

צ- اقتراح عدد من التوصيات التي تعد بمثابة معالجات للحد من تلك الظاهرة في

محاولة للقضاء عليها.

\section{أهمينة البحث}

تبدو أهمية البحث من أهمية موضوعه والذي أصبح في انتشار بـلا حدود في ظل غياب العقل والوعي مخلفاً بذلك آثاراً سلبية لا حد لها. فنتيجـة التطورات الحديثة التي أصبحت تضغى على المجتمع، خاصة ما تنادي بـه المجتمعات الغربية من التحرر

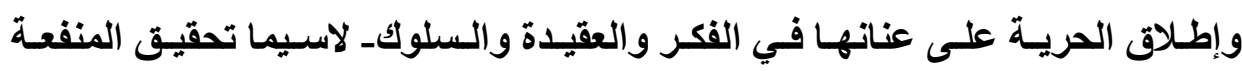
الجنسيةـ فكان لألك عظيم الأثر في تعارض تلك الأهداف مـع مقاييس ومعاني العرض والعفة، بل وأصبح لكل فرد الحرية المطلقة في أن يفعل مـا يريـ دون رقابـة من قانون أو خشية من عقائد، ولعل هذا هو الإطار الذي يدور فيه أهمية البحث. 


\section{هنهج البحث}

سوف نتبع على مدار البحث المنهج الوصفي التحليلي، القائم على وصف

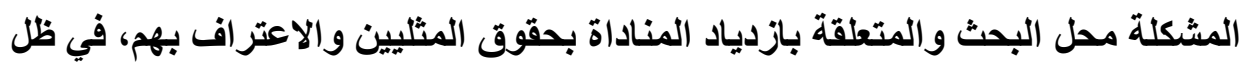

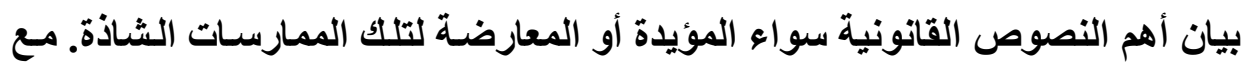

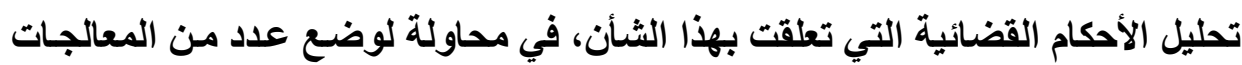

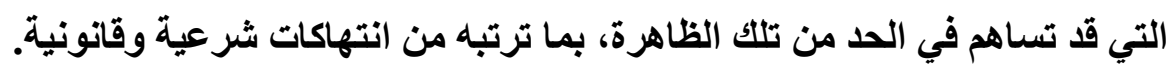

\section{تقسيم خطة البحث}

المبحث الأول: ماهية العلاقـات الجنسية المثلية الشاذة وانتهاكها لقواعد الدين

$$
\text { والأخلاق }
$$

المبحث الثاني: العلاقات المثلية الثاذة بين الإباحة والتجريم

المبحث الثالـث: آثـار العلاقـــات المثليـة الـشاذة على الفـرد والمجتــع وطـرق

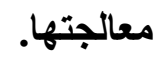




\section{المبحث الأول}

\section{هاهية العلاقات المثلية الشاذة وانتهاكها لقواعد الدين والأخلاق}

سوف نتناول من خلال هذا المبحث مفهوم العلاقة الجنسية المثلية الشاذة، وإلى أي أسباب ينتمـي إليها هذا السلوك، مـع بيـان كيفيـة انتهاكها لقواعد الشرع والقيم والأخلاق، وذلك من خلال تناولها في مطلبين على النحو التالي:

\section{المطاب الأول}

\section{هفهمم العلاقة الهنسية المثلية الشاذة}

تعـــ المثليــة السشاذة (Homosexuality) مسـصطاً عامــاً للتعبيـر عـن

العلاقات الجنسية لأفراد من نفس الجنس، أياً كان أطراف تلك العلاقة، فعندما تكون بين رجلين تسمى لواط أو مثلية ذكرية، وعندما تكون بين امرأتين تسمى سحاق أو مثلية أنثوية.

وقـــ ســاوى عــم الـنفس بـين لفظظ الشذوذ والاتحـراف، واعتبـر أن الـشاذ أو المنحرف "هو الأي يمارس انحرافات أو صور نشاط تناسلي ليس فيه اتفاق مع الثقافة أو الأعراف العامة لمجتمعه أو دولته"(') وتدل الثين والذال في الثذوذ على الانفراد 
و المفارقةـة، فيقـال شذا الشيء يشذ شـذوذاً، وشـذ شـذوذاً أي تفرد على الجماعـة أو

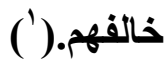

وعرف أحد الفقهاء المثلية بأنها "العلاقة الجنسية بين أفراد من نفس

الجنس و التي تتدرج من التخيلات والمشاعر وتمتد عبر التقبيل والاستمناء التبادلي إلى بلى

الاتصال الجنسي التناسلي أو الفمي أو الثرجي" (")

و أطلق البعض الآخر تعريفاً لها بوصفها نمطاً من أنماط الشذوذ الجنسي بأنها

"انحراف عن الطريق المحدد، فهي ضروب من الممارسة الجنسية يخرج فيه أصحابها

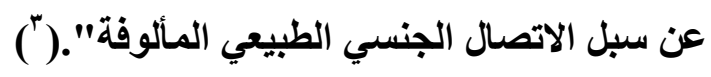

وقد يرجع السلوك الجنسي إلى وجود اضطرابات عضوية لدى ذويـه، والتي قد

ترجع إلى اختلال في معدل الهرمونات ووجود اختلال عصبي لديهم فضلاً عن إمكانية وجود شذوذ في الجينات الوراثية. وقد يغزى سبب الثذوذ الجنسي إلى فثنل في اكتمـال

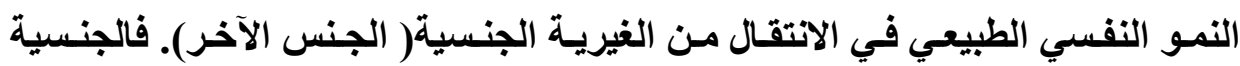

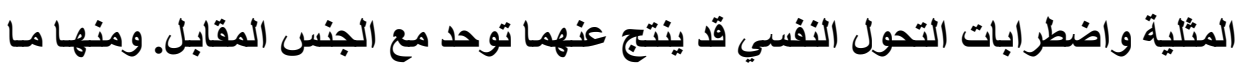
يرجع إلى الخبرات المبكرة والبيئية التي ينشأ فيها الطفل، والتي اعتاد فيها على لتى

(1) أبو الحسن أحمد بن زكريا ابن فارس " معجم مقاييس اللغة" دار الجيل، بيروت، الجزء الثالث،

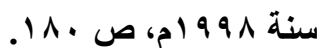

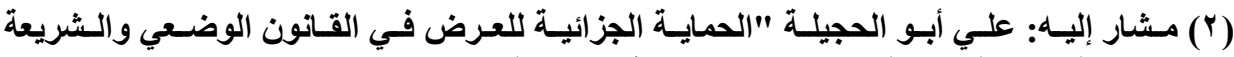

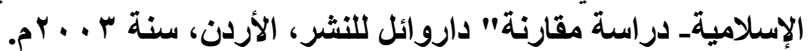

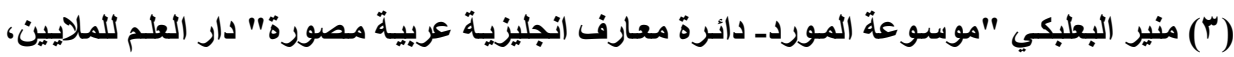

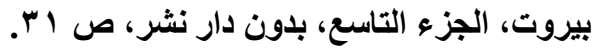


مزاولة السلوك الجنسي الشاذ إمـا بمحاكاته أو بممارسته ميع شخص آخر في مرحلة

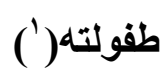

ولا يرتبط هذا السلوك بجيل أو فئة معين أو طبقة معينة في المجتمع، ولا ترتبط

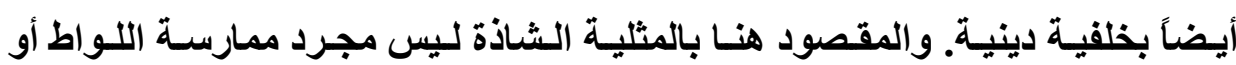
السحاق، بل يوجد أفراد طبيعيين يمارسون اللواطو السحاق دون أن يكونوا مثليين.

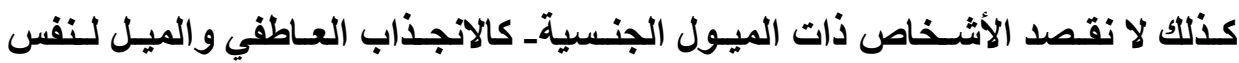

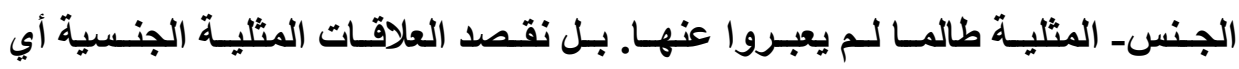
الممارسات الجنسية المثلية الفعلية.

\section{الاملب الثاني}

\section{انتهاك المثلية الشاذة لقواعد الدين والأخلاق}

حرمت الثرائع السماوية كافة أفعال المثلية الثاذة، ففي الايانة اليهودية اعتبر

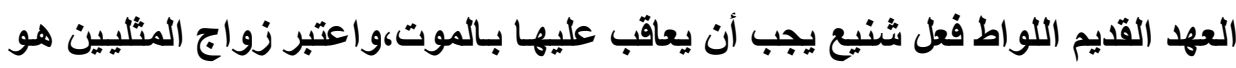

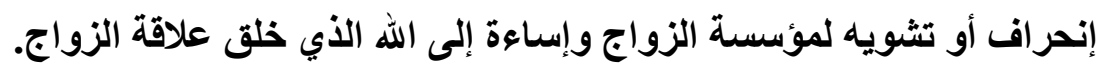
أمسا الدين المسيحي فقد نهى عنها واعتبرها فاحشة وخطيئة، وعاقب المثلـي

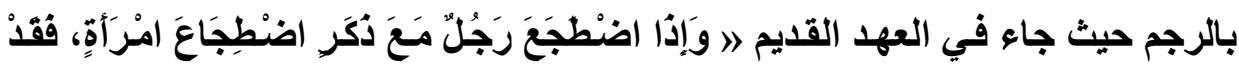

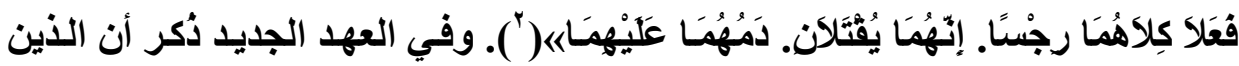

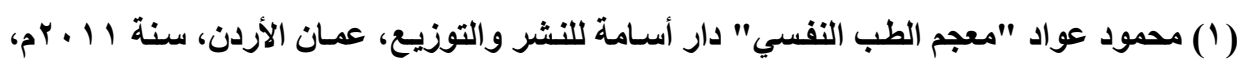

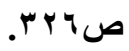

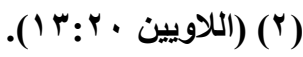




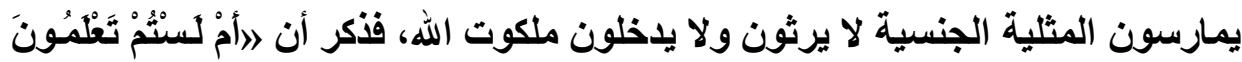

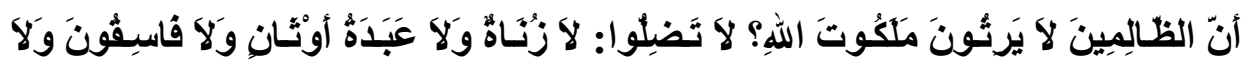

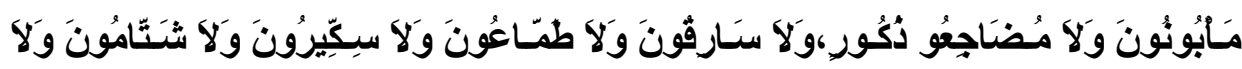

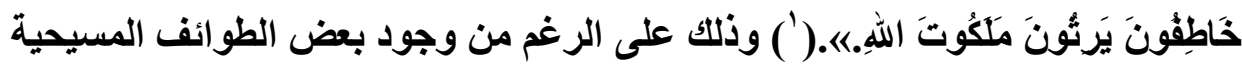
التي أصبحت تؤيد زواج المثليين وتدافع عن حقوقهم.

وأما الدين الإسلاميفمنذ أكثر من أربعة عشرة قرنـاً وقد نص بنصوصصريحة

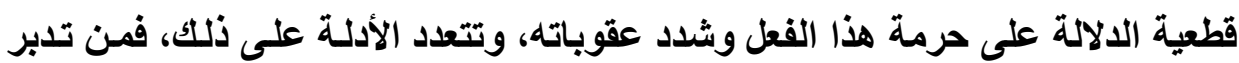

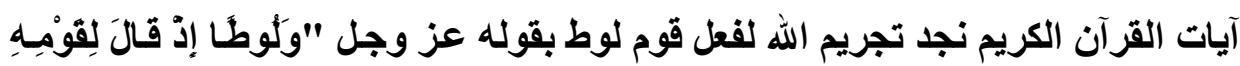

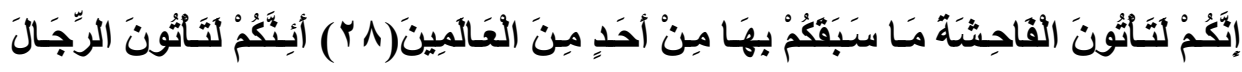

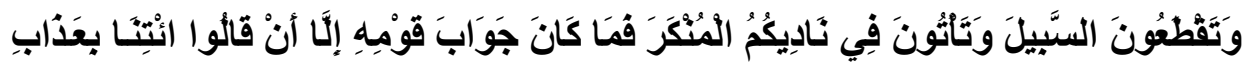

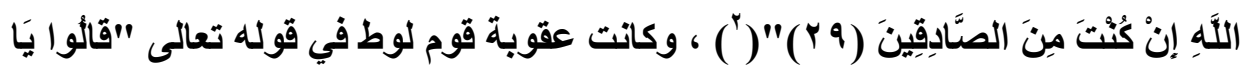

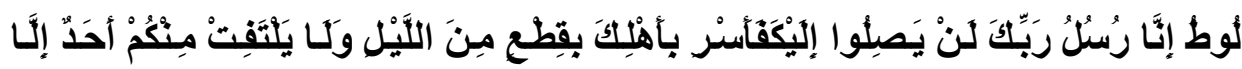

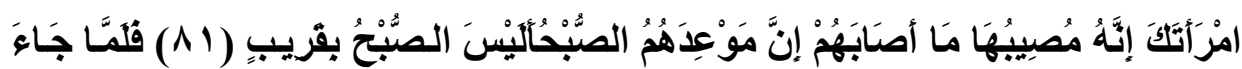

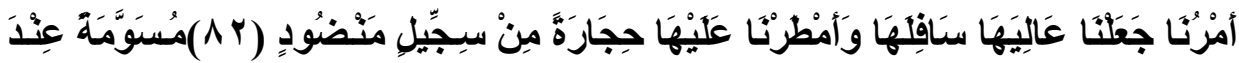

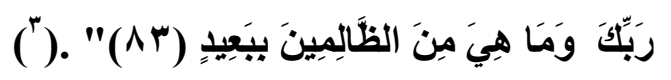

وفي الأحاديث النبوية الثريفة نجد ما يحرم تلك الأفعال، فعن رسول الله صلى بلى

الله عليه وسلم قال "من وجدتموه يعمل عمل قوم لوط فاقتلوا الفاعل والمعمول بهل"( أ)

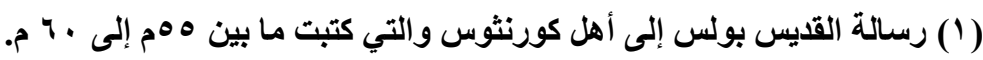

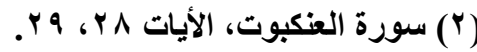

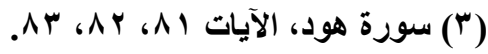

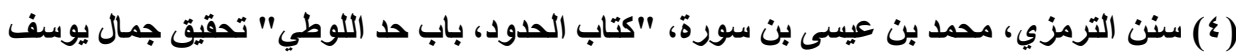

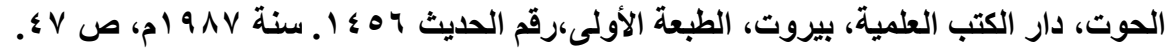


كذلك ما ورد عن النبي صلى الله عليه وسلم في تحريمه لفعل اللواط بقوله "إني أخوف

$$
\text { ما أخاف على أمتي عمل قوم لوط".) }
$$

ولا عقاب على مجرد الميل إلى ممارسـة تلك الأفعال الشاذة،والتي لا ترقى لأن

تكون عزيمة أو تصميماً، ولا يترتب عليها قول ولا فعل، فلا يعاقب عليه الإنسان مهمـا كان سيئًا، "وتؤكد أحكام الشريعة على أن مجاهدة صاحبه له، علامة على تقواه، وتعد من الطاعات الكبار التي يستحق عليها الثواب والمدح، وعلى ذلتك فلا يجوز محاسبة الإنسان ومعاقبته أو ازدراؤه على مجرد ميل يوجد فيه بغير تكلف، ولا يتبع فيه نفسه هواها، بل ينبغي أن يعان على الخير واجتناب الفواحش ما ظهر منها ومـا بطن، وعلى تهي من ابتلي بشيء من ذلك أن يتحلى بالصبر الجميل، على مجاهدة مـا يجده بداخله من ميل منحرف، وعلى مـا يجده مـن معاملـة النـاس لـه".(") ويجب معاملة مثل هؤلاء معاملة حسنة تناسب حالهم ومجاهدتهم لشرور أنفسهم، وتعينهم على مـا يجدونـه من . اضطراب نفسي أو عضوي . ترتيباً على ماسبق فـلا خـلاف في حرمـة الشذوذ الجنسي، سـواء اللـواط بين الـكور، أو السحاق بـين الإنـاث، ومــا يسبق ذلـك مـن مقدمات. وأمسا عقوبـة هـاتين الجريمتين: فمختلة، فاللواط حده القتل، وأما السحاق فليس فيه حد، وإنما فيه التعزير لأنه ليس زنى.(r) ولا تصح معاملة الفاعل في تلكك الأفعال المجرمـة معاملة المرضى

(1) الحاكم النيسابوري "المستدرك عن الصحيحين" مطبعة النصر، الرياض، الجزء الرابع، بدون

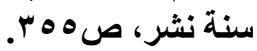

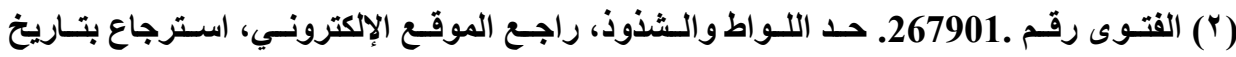
http://fatwa.islamweb.net $.11 / \% / r$.

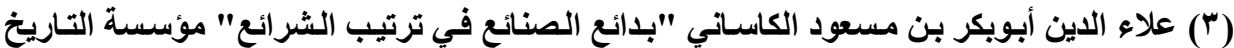

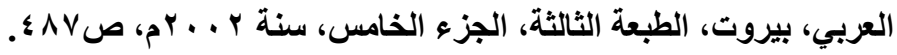


النفسانيين، ولا ترفع عنهم المسؤولية ويجدون ما ييرر فعلهم أو يخفف من عقابهم. بل لابد من وعظهم وردعهم وعقوبتهم عن الخطأ المترتب على فعلهم باعتباره من أعظم

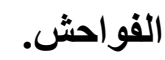

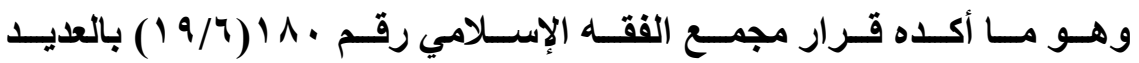

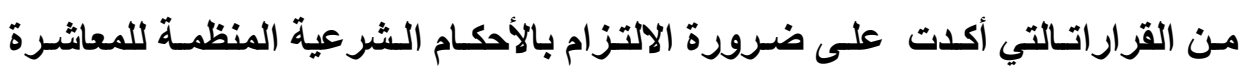

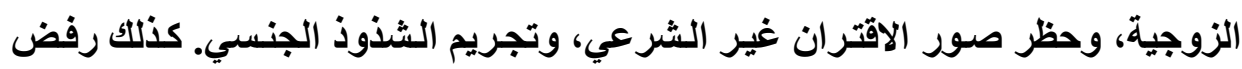

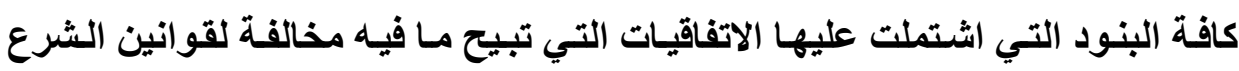

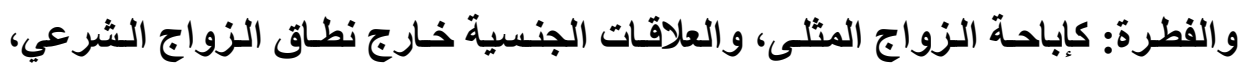

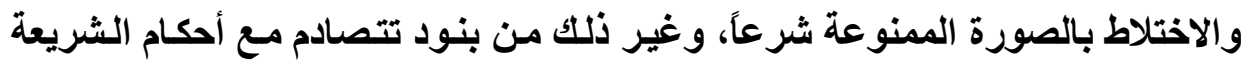

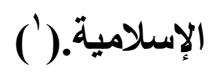

(1) قرار بشأن العنف في الأسرة، ضمن قرارات مجمع الفقه الإسلامي الدولي المنبثق عن منظمة

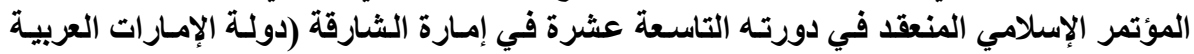

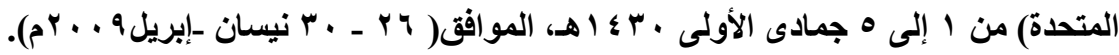




\section{المبحث الثاني}

\section{العلاقات المثلية الشاذة بين الإباحة والتجريم}

المثلية الثناذة ظاهرة اختلفت الدوافع التي أدت إلى تناميها في المجتمع، وكسان

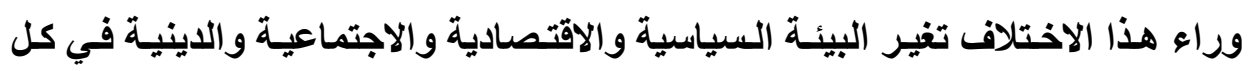

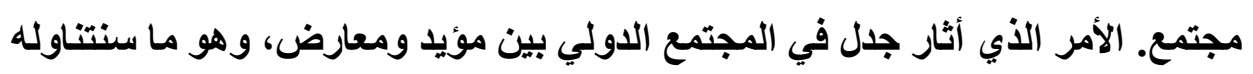

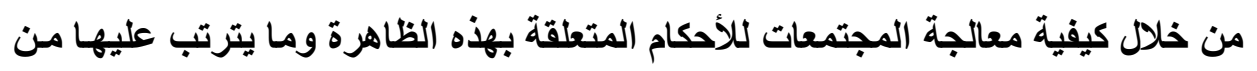
آثار قانونية،وذلكك من خلال المطالب التالية:

\section{المطالب الأول}

\section{هوقف الأنظمة القانونية المعارضة والرافضة للمثلية الشاذة \\ أولاً: اتجاه كثير هن التشريعات إلى رفض العلاقات المثلية}

القانون أساسه قواعد الاين والأخلاق باختلاف طرق التعبير عنه-تبعاً لاختلاف

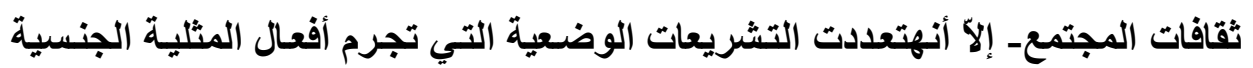

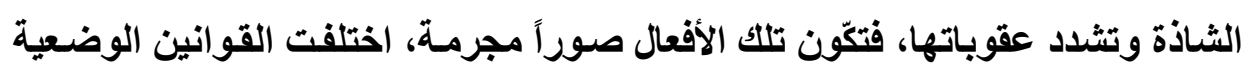
في طرق التعبير عنها.

ففي القانون المصري لم نجد نصاً صريحاً يعالج مسألة الجنسية المثلية أو أية إثـارة مباثرة للميول الجنسية الثاذة، إلا أنسه وفقًا لنص المـادة الأولى من القانون

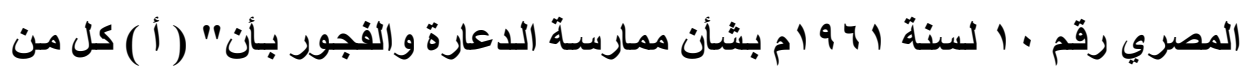
حرض شخصاً ذكراً كـان أو أنثى على ارتكاب الفجور أو استترجه أو أغواه بقصد 
ارتكـاب الفجور أو اللدعارة يعاقب بـالعبس مـدة لا تقل عن سنة ولا تزيــ على ثـلاث

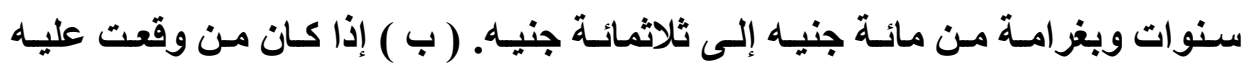
الجريمة لم يتم من العمر الحادية والعشرين سنـة ميلاديـة كانت العقوبـة الحبس مدة لا

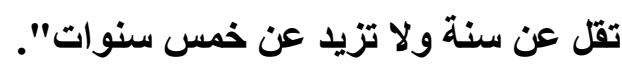

كمـا تضمنت المـادة 9 من نفس القانون النص على أنهلهعاقب بـالحبس مدة لاتقل عن ثلاثة أشهر ولاتزيـ على ثُلاث سنوات وبغرامـة لاتقل عن خمسة وعشرين جنيهًا ولاتزيد على ثلاثمائسة جنيه أو بإحدى هـاتين العقوبتين: (أ) كل من أجر أو قدم بأية صفة كاتت منزلا أومكائًا يدار للفجور أو الدعارة أو لسكنى شخص أو كثر إذا كـان يمارس فيه الفجور والدعارة مع علمه بذلك .(ب) كل من يملك أو يدير منزلا مفروشـاً أو غرفاً مفروشـة أو محلا مفتوحاً للجمهور يكون قد سـهل عـادة الفجور أو الدعارة، سواعبقبوله أشخاصساً يرتكبون ذلك أو بسماحة في محله بـالتحريض على الفجور أو الدعارة (ج) كل من اعتاد ممارسة الفجور أو الاعارة".

وعلى الرغم من غموض النص ـسالف الذكر- والذي لم يحدد صراحة ما الفرق بين اللفظين (الدعارة والفجور)،إلا أن الغموض لا يحول دون تفسيره على هدى مـا يستخلص من قصد الثارع، ولذلك فسرت أحكام القضاء هذا النص وبينت مـن مفهوم دلالـة هذا النص، أن الجريمـة المنصوص عليهـا فيـه لا تتحقق بـدورها إلا بمباشـرة الفحشاء مع الناس بغير تمييز وأن يكون ذلك على وجه الاعتياد سواء بالنسبة لبغاء الرجل أو بغاء الأنثى، والأنثى حين ترتكب الفحشاء وتبيح عرضها لكل طالب بـلا تمييز فتلك هى الاعارة ، تنسب للبغى فلا تصدر إلا منها ، ويقابلها الفجور وينسب للرجل حين يبيح عرضه لغيره من الرجال بغير تمييز فلا يصدر إلا منه(1)

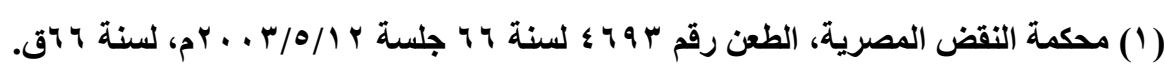

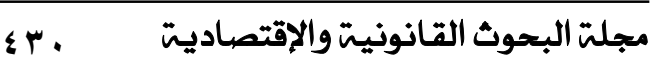


أما نص القانون الكويتي فقد تضمن تجريم الأفعال التي تمثل شذوذاً، وذلك في

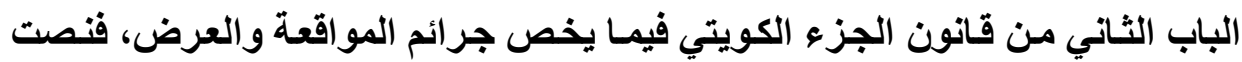

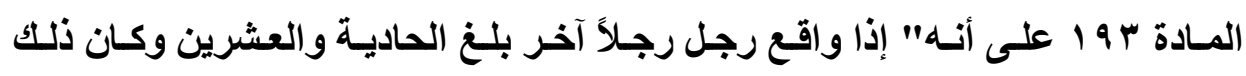

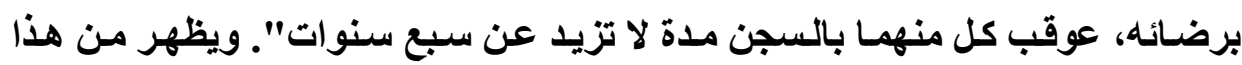

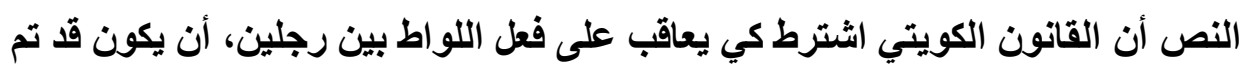

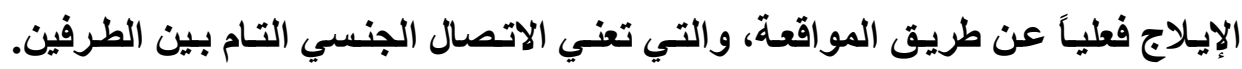

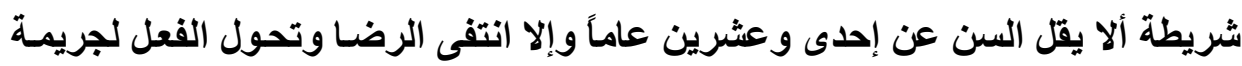
هتك عرض.

كما نص قانون العقوبات الجزائري في المـادة ^بr منه على أنه "تتم معاقبة أي شخص يثبت عليه ارتكاب الممارسات الجنسية المثلية، بالسجن لمدة تتراوح بين

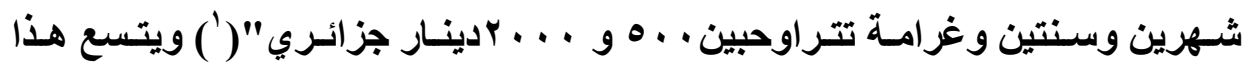

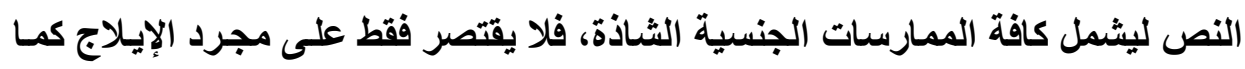
هو الحال في القانون الكويتي، بينما تضمن كل الممارسات الجنسية المثلية كالملامسة الإسة والتحسس ووضع العضو التناسلي في فم الطرف الآخر.

وفي دولة غامبيا يعاقب القانون الصادر سنة هو 9 الم ام و المعدل في أغسطس

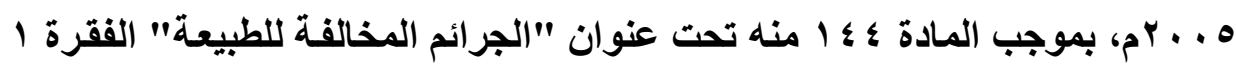

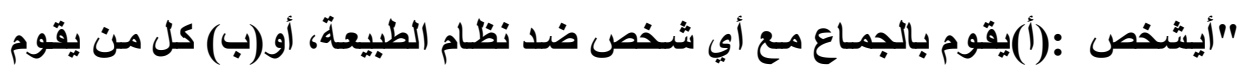

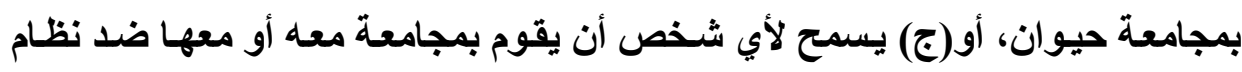

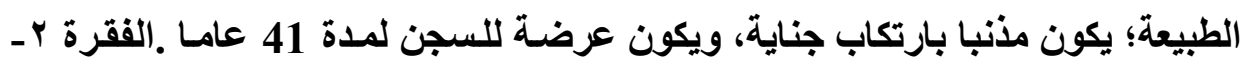

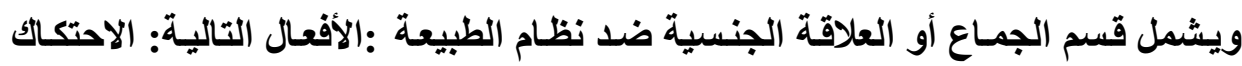


الجسدي مع الثخص من خلال فتحة الشرج أو فم الشخص، كذلك إدخـال أي عضو أو شيء في فرجـأ وفتحة شرج للشخص لغرض محاكساة الجنس، وارتكاب أي فعل آخر

$$
\text { مثلي الجنس مع شخص"( '). }
$$

وفي أوغنـا أصدر رئيس الدولـة قـانون لمكافحة المثليـة الجنسية في فبراير

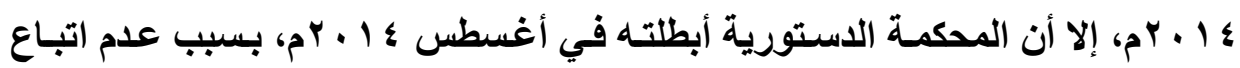

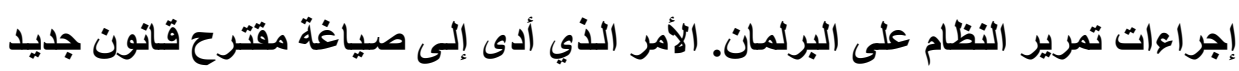

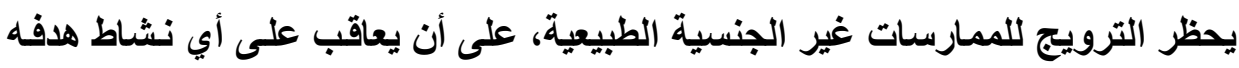

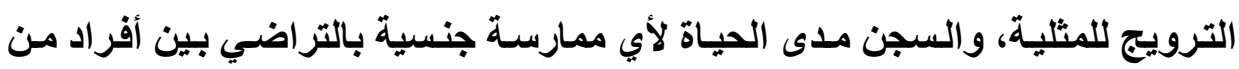

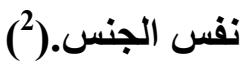

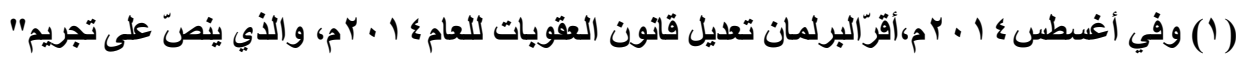

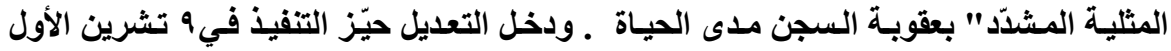
/أكتوبر2014م ويضمّ المواد التالية:

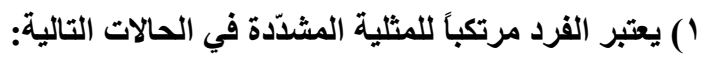

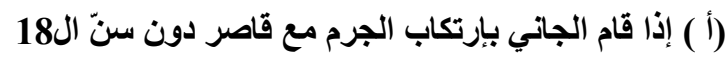

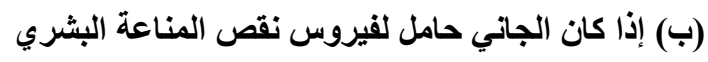

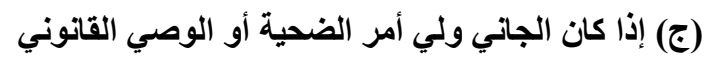

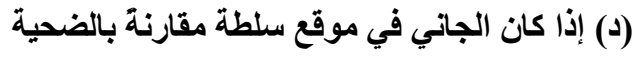

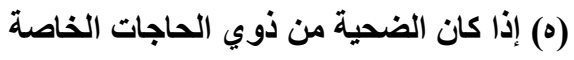

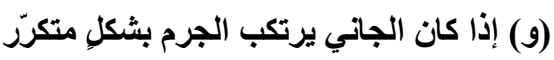

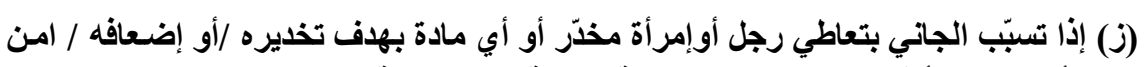

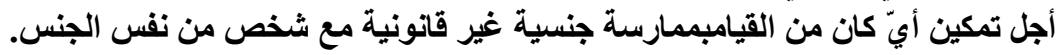

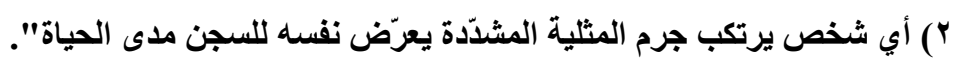

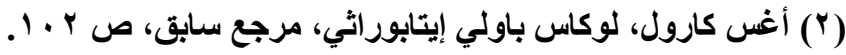




\section{ثانيًا: الأركان العاهمة في جرائم المثلية الشاذة}

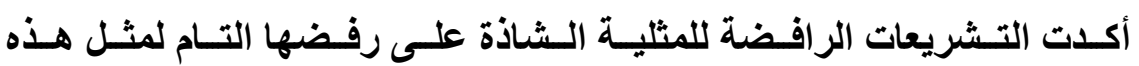
الممارسـات، بوضـعها سياجاً قانونياً في محاولة للحد من ارتكـاب تلك الأفعـال وردع مرتكبيها.وقد أوردتتلك التشريعات نصوصاً تتضمن تجريم أفعال الممارسـات الجنسية

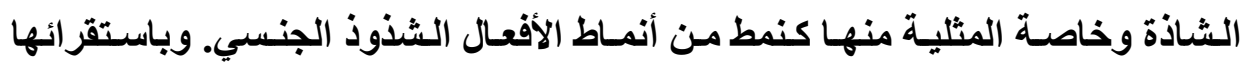
وجدنا أن الأركان العامة المكونة لهاتتمثل على التحو التالي:

أ- الركن المادي في جرائم الشذوذ: يتمثل في أي فعل من أفعال الاتصال الجنسي

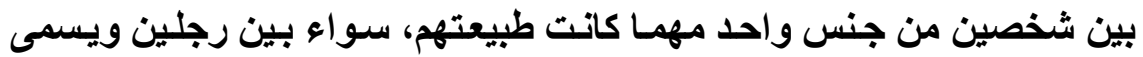

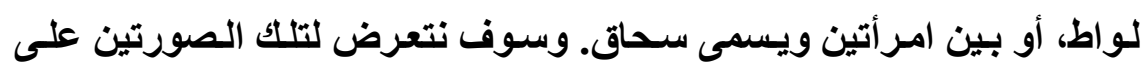

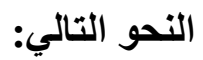

\section{الصورة الأولى: اللواط}

يعرف اللواط لغة في باب اللام والواو والطاء كلمة تدل على اللصوص، يقال لاط

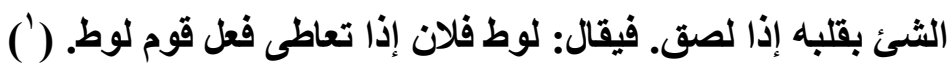
ويعرف اللواط اصطلاحاً عند الأحنـاف بأنـه الوطع في اللدبر في الأنثى أو

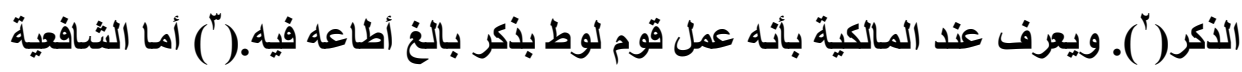

(1) أحمد بن زكريا ابن فارس "معجم مقاييس اللغة" تحقيق عبدالسلام محمد هارون، دار الجبل،

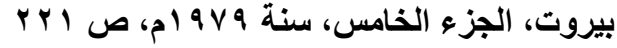

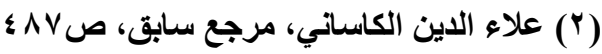

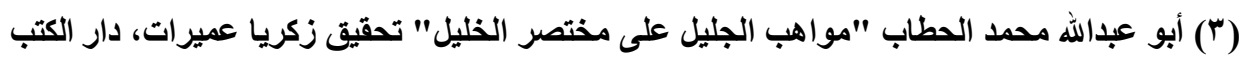

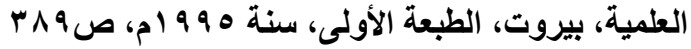


فذهبوا إلى مـا ذهب إليهم الأحنـاف في أنـه إيلاج ذكر في دبر ذكر أو أنثى.(') وعند

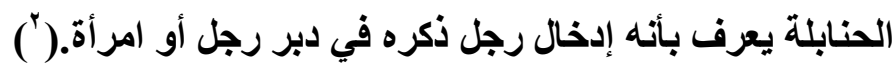
أما في مصطلحات النصوص القانون، فقد عرفهالقانون السوداني صراحة بقوله "أي رجل يقوم بإيلاج قضييه أو مايعادله في فتحة الشرج لامرأة أورجل أو يسمح فئل لرجل آخر بإخال قضيبه أومايعادله في شرجه يكون قد ارتكب اللواط" أما القانون الماليزي تضمنت المادة rVV عقوبات منه تعريف اللواط بأنه"كل شخص يقوم بالاتصال الجنسي مع شخص آخر من خلال إدخال القضيب في فتحة شرج أو فم شخص يكون قد ارتكب الجماع الجنسي ضد نظام الطبيعة". ويتبين مما سبق أن الثرط المفترض في جريمة اللواط كصور من صور جرائم

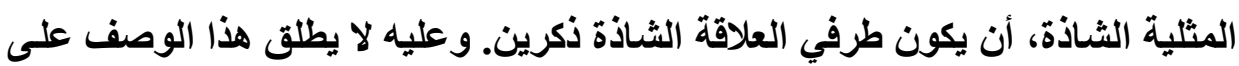
احتكالك متبادل بين انثتين، كذلك لا يعد لواطاً اتصال الإنسان مع حيوان. بناء على ذلك فبان السلوك الإجرامي المكون لفعل اللواط يتم بإنخال قضيب

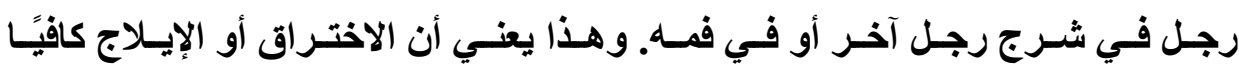

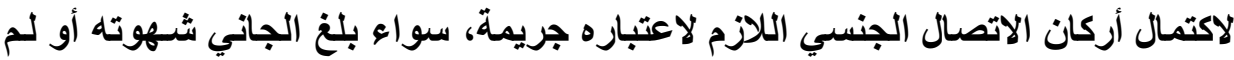

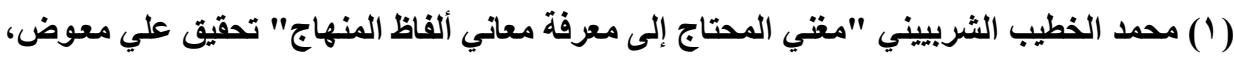

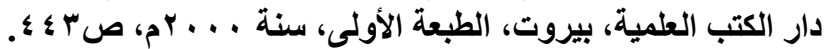

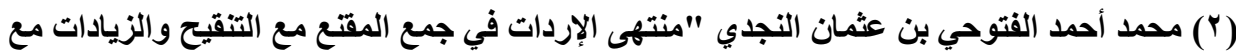

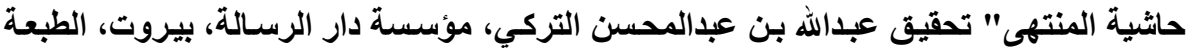


على خلاف ما اشترطه التشريع الإسلامي للعقاب على فعل الوطء أن يكون في

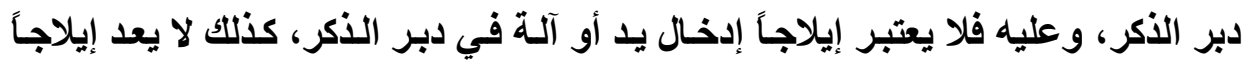
وضع العضو في غير الفرج كالإبط أو الفم أو الخلوة.

\section{الصورة الثانية: السحاق}

يعرف السحاق لغة بأنه: امرأة سحاقة كنعت سوء('). ويقال سحق سحقاً: دقه

$$
\text { أشد الاق، وانسحق الثنئ: اتسع.(") }
$$

أما اصطلاحاً فيعرف بأنه" (نحراف جنسي تحصل فيه الأنثى على اللذة الجنسية

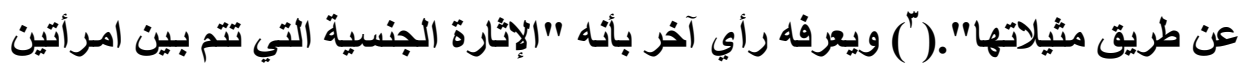

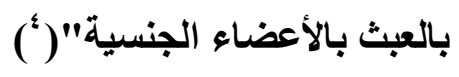

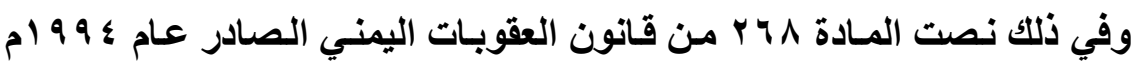

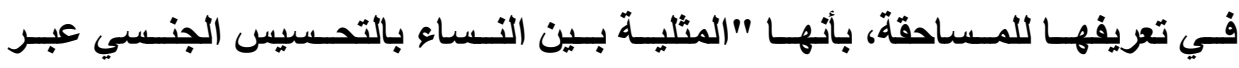
الإحتكاك . تعاقب الممارسـة التي تتّّ عن سـابق تصور وتصميم بالسجن مدّة تصل إلى 3 سنوات؛ وفي حال الإكراه على الممارسة تعاقب الجانية بالسجن مدّة تصل إلى 7

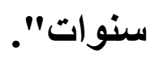

(1) مجد الدين يعقوب الفيروز آبادي" القاموس المحيط" تحقيق مكتبة التراث، مؤسسة الرسـالة،

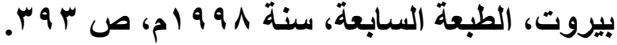

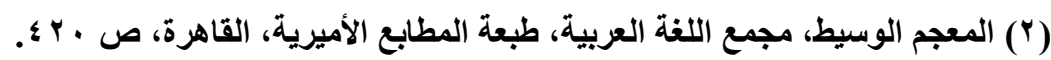

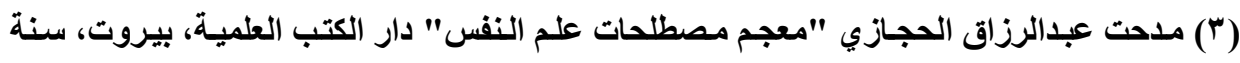
rr. (؛) إدوارد غالي الذهبي " الجرائم الجنسية وإثباتها" دار النهضة العربية، القاهرة، الطبعة الثانية،

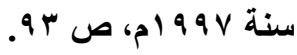


ويتبـين مــن نـصوص المــواد ســابقة الـــكر أن الـسلوك المرتكـب فـي

صـورة فعل السحاق يقتصر على مجرد التلـذذ الجنسي مثل التحسيس والمداعبـة والتدالكك وغير ذلك من ضروب الممارسات ذات المسحة الجنسية. وهو مسالا يدخل في مُ في فعل الزنـاوالذي يشترط فيـه إيـلاج العضو الذكري، وهو مـن المستحيل حدوثه بين

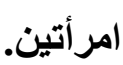

وفيمـا يتعلق بالنتيجـة الإجرامية في كلتـا الصورتين، فلا يشترط وقوع نتيجة معينة، فتعد تلك الأفعال من صور الجرائم الثكلية، التي تقف عند حد تطلب الخطر دون

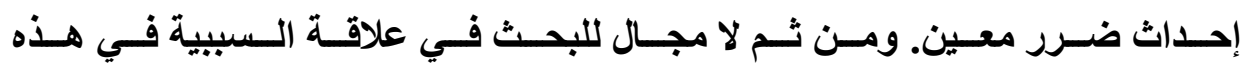

\section{ب- الركن المعنوي في جرائم المثلية الجنسية}

اشترطت أغلب التشريعات أن يصدر الفعل عن الجاني عمداً، ويتحقق ذلك كلمـا

ثبت أن الجاني يعلم بما يرتكبه من ممارسات جنسية غير مشروعة، واتجاه إرادته إلى تحقيق الفعل المجرم أو القبول بـه وتحقيق الاتصال بطريقة شــاذة مخالفة للفطرة. أيـاً كان الباعث على ارتكاب هذا الفعل. وعليه فالقصد الجنـائي المتوافر في جرائم المثلية قصداً جنائياً عاماً.

فلا يتطلب القانون قصداً خاصاً اكتفاءً بالقصد العام، ولا يلزم في القانون أن يتحدث الحكم استقلالاً عن هذا الركن، بل يكفي أن يكون فيما أورده من وقائع وظروف

$$
\text { ما يكفي للالالة على قيامه.() }
$$

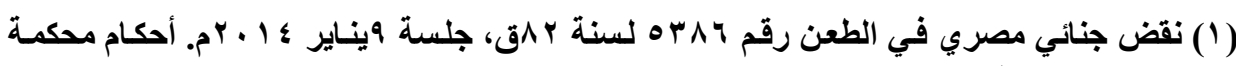
النقض المصرية. 


\section{ثالثً: الشروع في جرائم المثلية الشاذة}

تعاقب أغلب القوانين على الثروع في ارتكاب جرائم المثلية الثاذة، والتي من

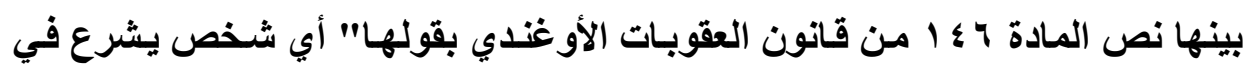
ارتكاب أي من الجرائم المنصوص عليها في المادة 145 يكون قد ارتكب جناية ويعاقب

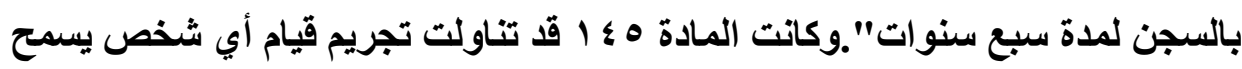

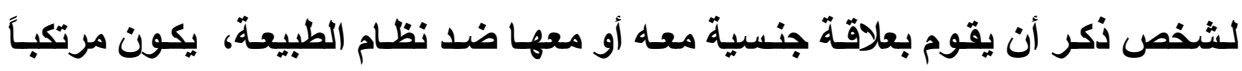
لجناية ويعاقب بالسجن مدى الحياة.

وقضت المحكمة الجزائية السعودية بأن قيام المدعي عليه بنزع شعر صدره

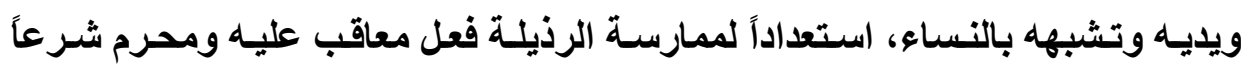
"حيث قضت بتعزير المدعي عليه، في واقعة تتلخص في توافر معلومسات لاى هيئة

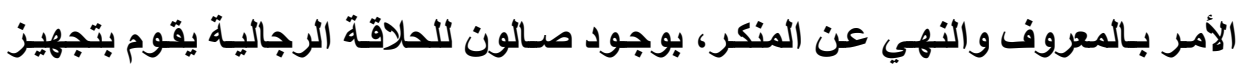

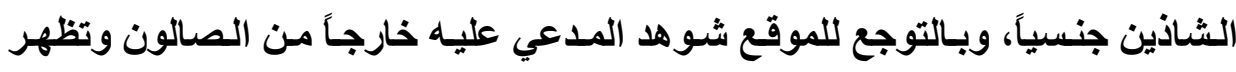

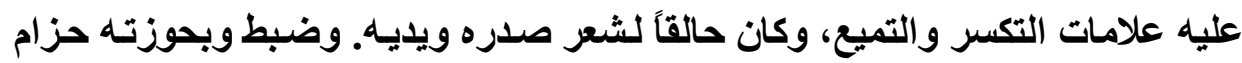
وحذاء ونظارات وعطور نسائية، ويفح جواتئه واله تم العثور على مجموعة من الصور

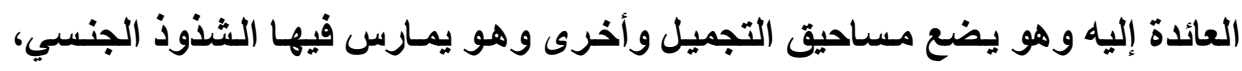
واعتبرت المحكمة أن ما قام بـه فعل محرم ومعاقب عليه شرعاً، وتم تعزيره بالسجن

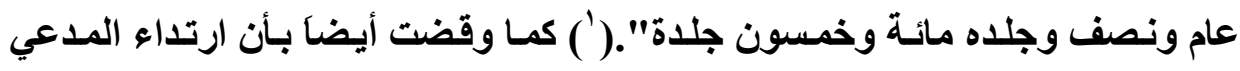

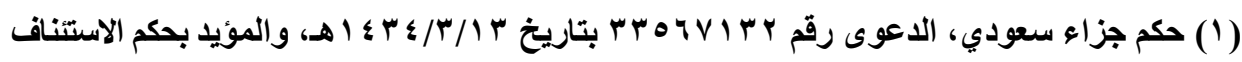

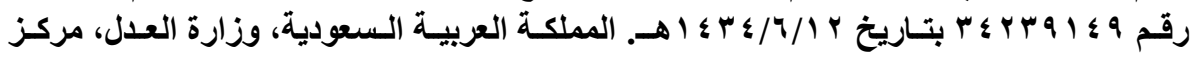

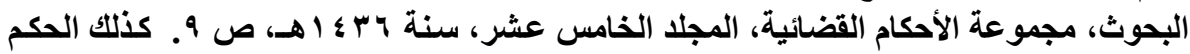

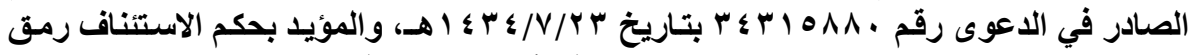

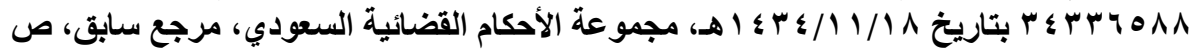


عليـه لملابس ضيقة وقصيرة ووضـع أحمر شـفاه ويـودرة على وجهه يعد تشبهه بالنساء، وهو من قبيل أفعال الثذوذ الجنسي المعاقب عليه شرعاً بـالتعزير.(') ونرى نحن أن تلك الأفعال من قبيل الشروع، كأن يرتكب الجـاني في مثل هذه الصور لمجرد جذب الطرف الثاني إليه، وإثارة من هو شاذ مثله. وعلى الرغم من ذلك تعاقب بعض هن

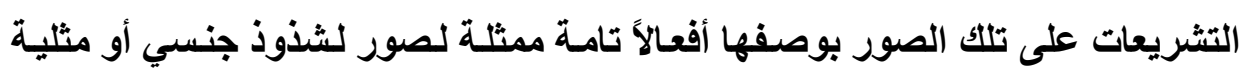
جنسية.

وتقع الجريمة تامة في بعض التشريعات، مادام أن الشروع في التحريض معاقباً

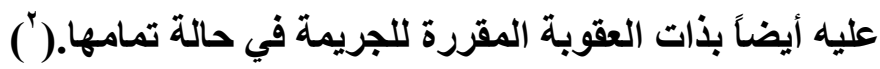

رابهًا: المساهـمة الجنائية في ارتكاب جرائم المثلية الشاذة

تعاقب أغلب القوانين الجنائية على المساهمة في التحريض أو المساعدة في

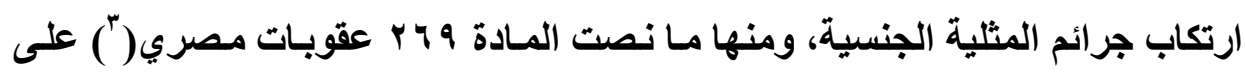
معاقبة كل من قام بالتحريض على ارتكاب أفعال تدل على الفست بقوله" يعاقب بالحبس

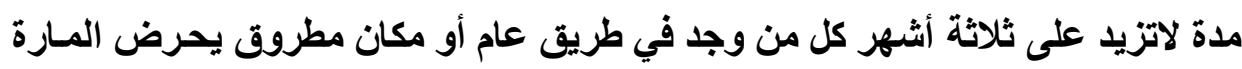

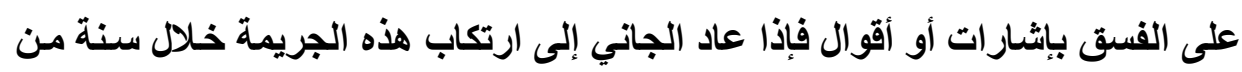

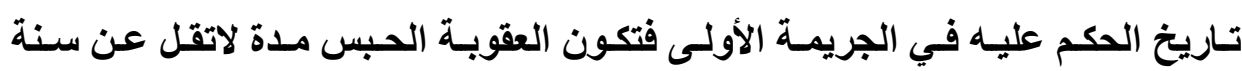

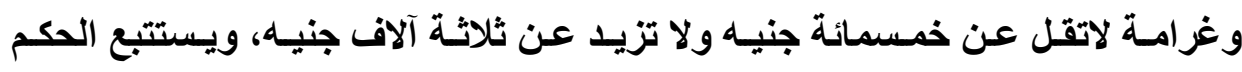
بالإدانة وضع المحكوم عليه تحت مراقبة الشرطة مدة مساوية لمدة العقوبة".

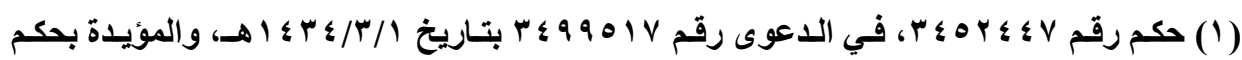

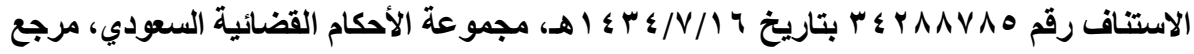

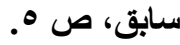

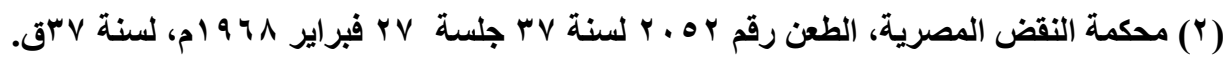

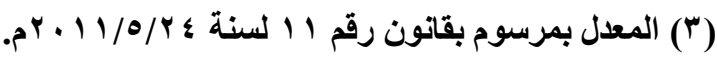


ومتى كـان القـانون لـم يبين مـا هو المـراد مـن كلمـة تحريض فِإن تقدير قيـام التحريض أو عدم قيامه من الظروف التي تخضع لتقدير محكمة الموضوع. وعليه فإذاذا

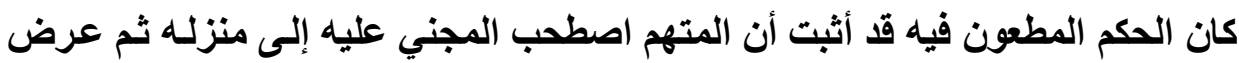

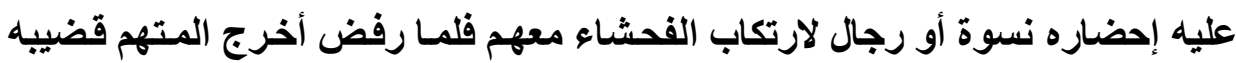

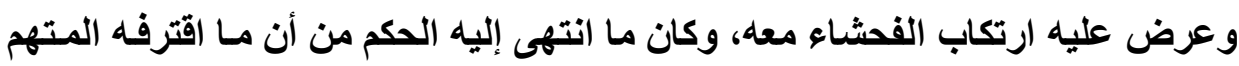
هو ضرب من ضروب التحريض على ارتكاب الفجور وإرضساء شـهوات الغير وليس إنه

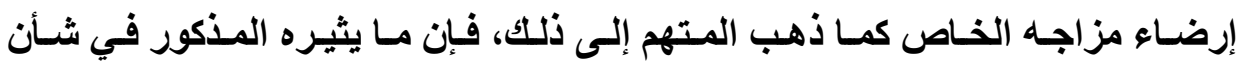
العناصر المكونـة للتحريض لا يعدو أن يكون مجادلـة في موضـوع الـدعوى لا يجوز إثارته أمام محكمة النقض(1) ونشر حكم المحكمة العليـا في أوغنـا في يوليو \& 1 ـ بم، في قضية رفعها

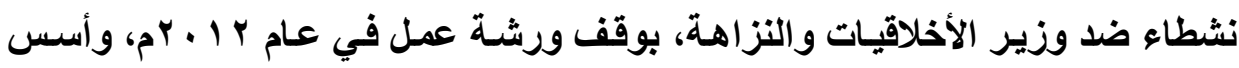
القاضي حكمه في تلك اللدعوى على أسساس أن المشاركين كانوا يروجون ويحرضون وفئن

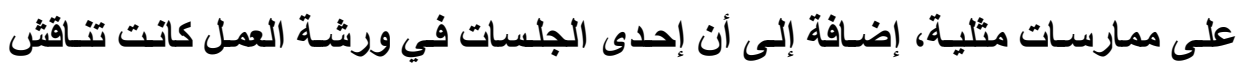

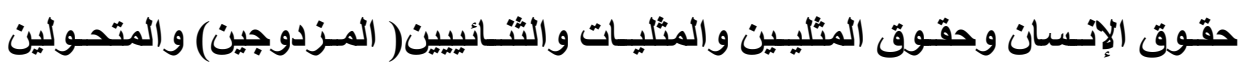

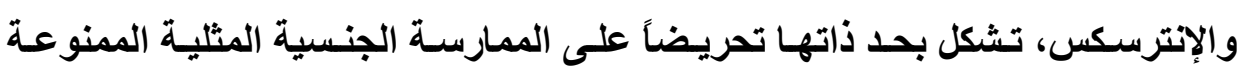

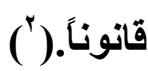

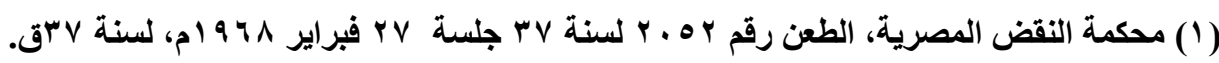

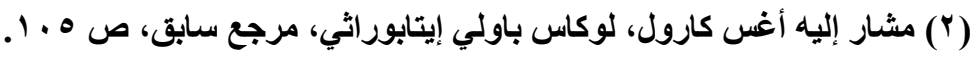




\section{المطالب الثالث}

\section{هوقف التشريعات المرئدة للجنسية المثلية الشاذة}

\section{أولاً: هوقف التشريعات المؤيدة لزواج المثليين}

تعتبر الدول المؤيدة للمثلية الجنسية أن محاربة تلك الممارسـات ومنعها، يعد

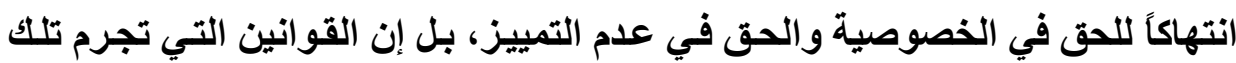

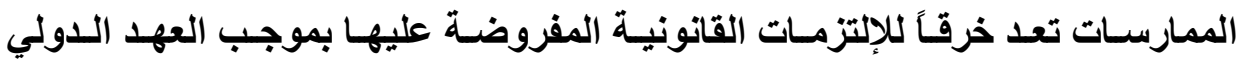

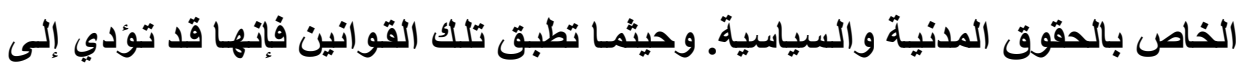

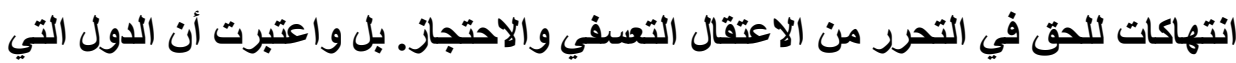
توقع عقوبـة الإعدامـ كمـا هو الحسال في إيران ومورتنيـا والسعودية وغير ذلتك مـن الدول- على السلوك الجنسي القائم على التراضي بين بالغين من نفس الجنس، إنما تعد إندان

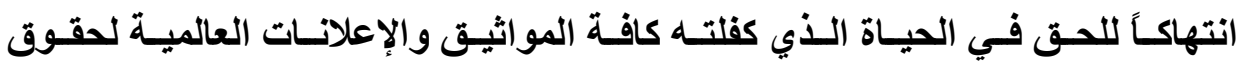

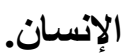

وقدأثيرت مسألة دستورية الزواج المثلي في بعض التشريعات والتي من

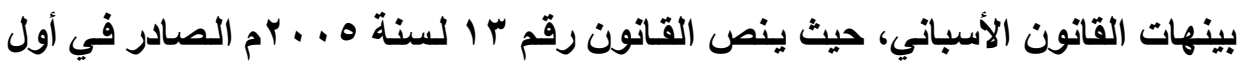

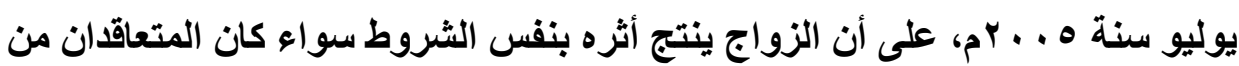
نفس النوع أو من نوع متماثل( ').

(1) Décision rendue par Cour constitutionnelle d'Espagne06-11-2012, $\mathrm{n}^{\circ}$ 198/2012 , Mariage entre personnes de même sexe : validation de la loi espagnole, Recueil Dalloz 2012 p.2890. 


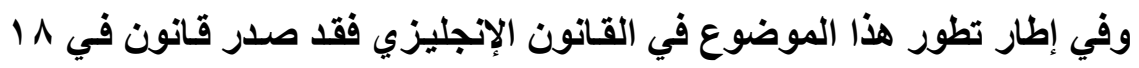

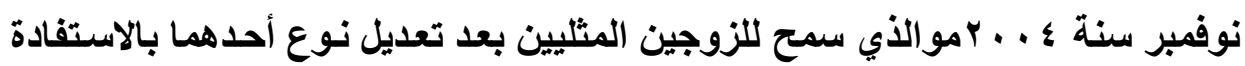

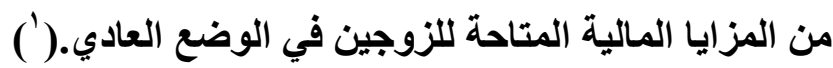

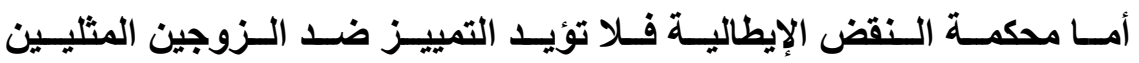

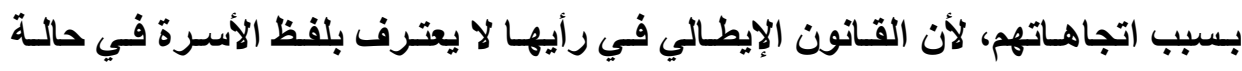

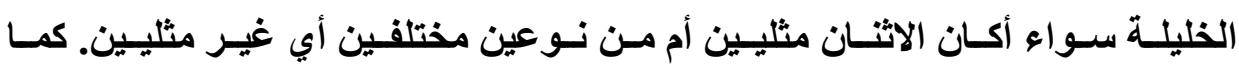

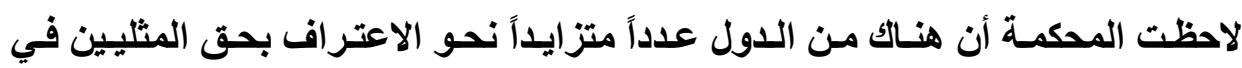

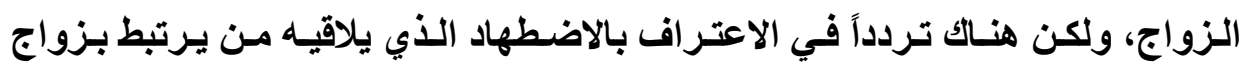

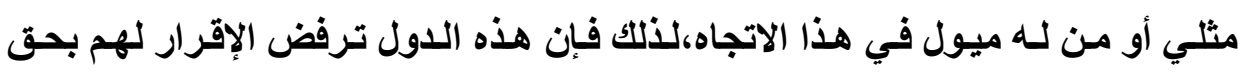

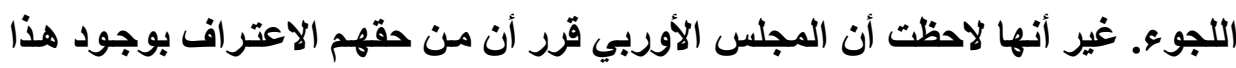

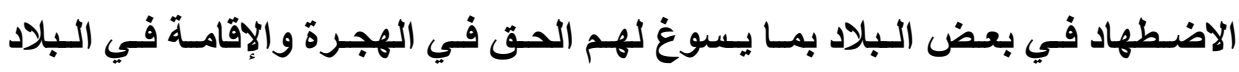

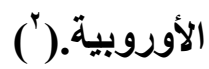

وفي فرنسا أجساز المشرع الفرنسي الزواج بين المثليين بمقتضى القانون

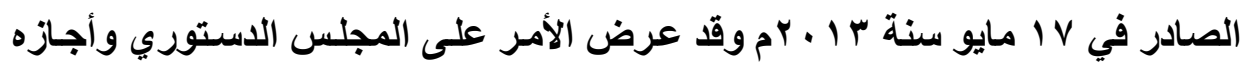

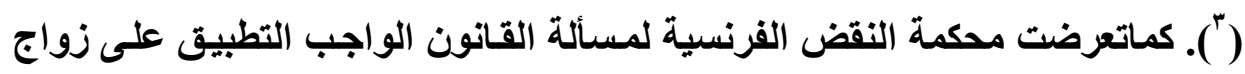

(1) les dispositions sur l'union civile instituée par une autre loi britannique du 18 novembre 2004 (cf. J. Flauss-Diem, Le civil partnership en droit anglais, in J. Flauss-Diem et G. Fauré (dir.), Du PACS aux nouvelles conjugalités : où en est l'Europe ?, Puf, 2005, p. 67.

(2) AFFAIRE TADDEUCCI ET McCALL c. ITALIE, 30 juin 2016. (Requête no 51362/09).

(3) Cons. const., 17 mai 2013, $n^{\circ}$ 2013-669 DC, Loi ouvrant le mariage aux couples de personnes de même sexe, JORF du 18 mai 2013, p. 8281, D.

$=$ 
المثيلين بخصوص زواج شخص من جنسية فرنسية وآخر من جنسية مغربية. وقد تمسكت النيابة العامة في رفضها للاعوى التي أقامها الزوجان إلى أن هناك اتفاقية بين

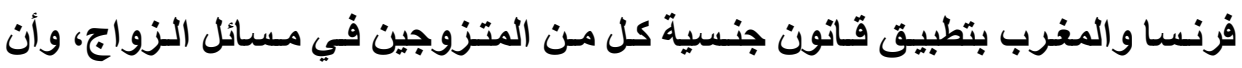

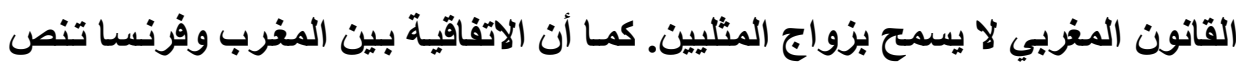

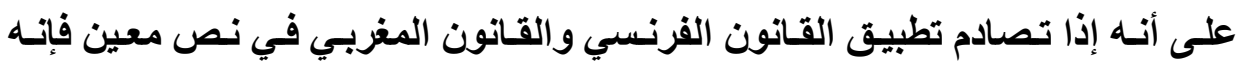

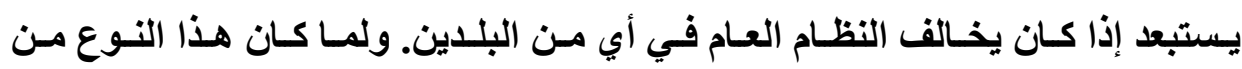

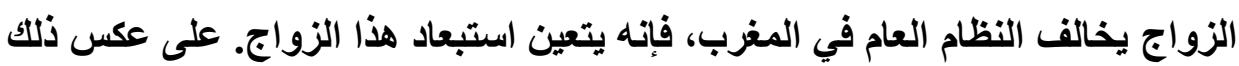

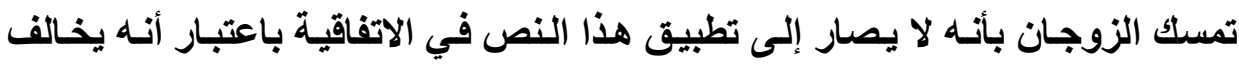

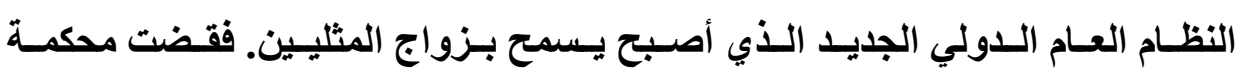
النقض الفرنسية بأولوية تطبيق الاتفاقية بين المغرب وفرنسا على تطبيق أي قانون

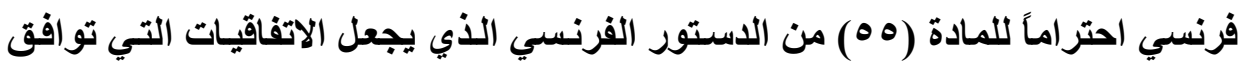

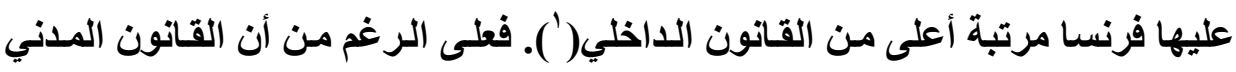

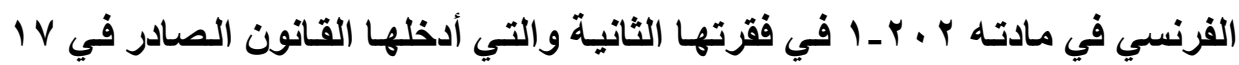

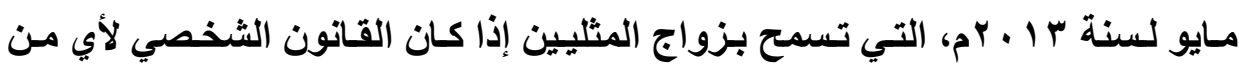

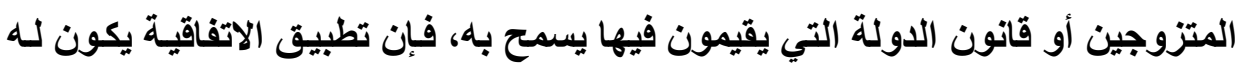

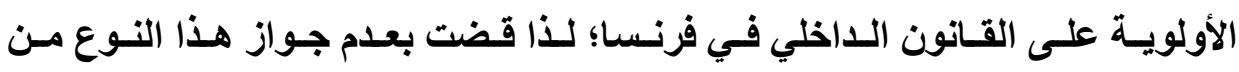

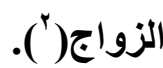

2013. 1643, chron. F. Dieu ; AJ fam. 2013. 332, étude F. Chénedé眘; Constitutions 2013. 166, obs. A.-M. Le Pourhiet.

(1) Cour de cassation ,28 janvier 2015 - $\left(\right.$ Civ. $\left.1^{\text {re }}\right)$.

(2) Didier Boden, Sylvain Bollée, Bernard Haftel, Petra Hammje, Pascal de Vareilles-Sommières, Mariage de personnes de même sexel : exception d'ordre public: Civ. $1^{\text {re }}, 28$ janv. 2015, $\mathrm{n}^{\circ} 13-50.059$, D. 2015. 464, obs. I. $=$ 


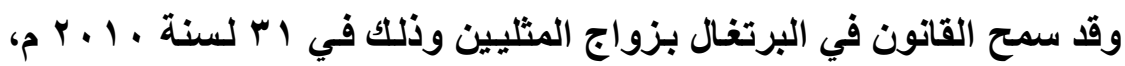

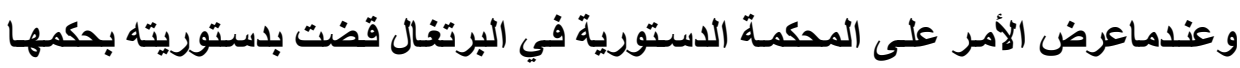

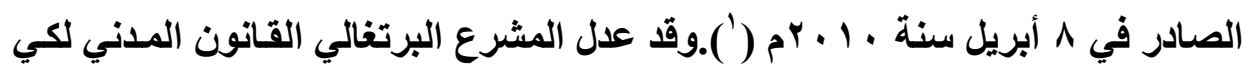

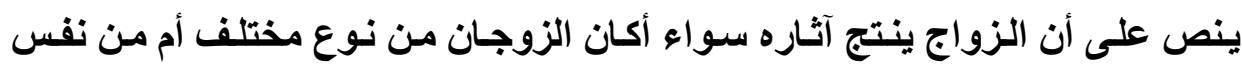

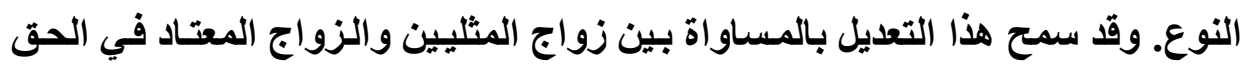

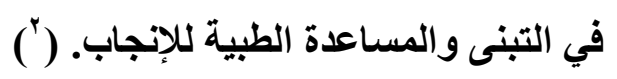

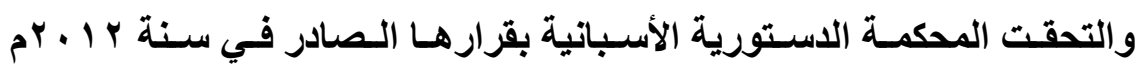

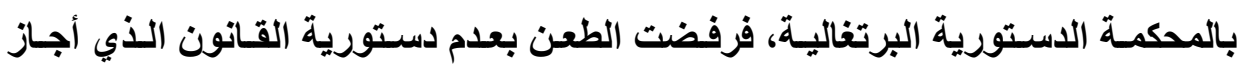

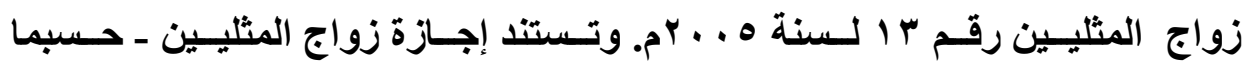

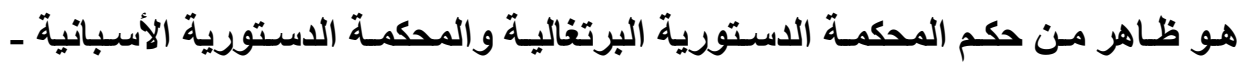

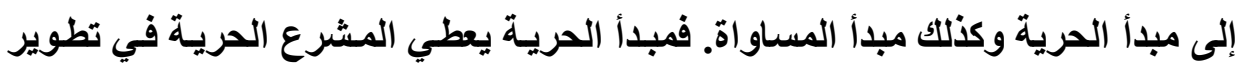

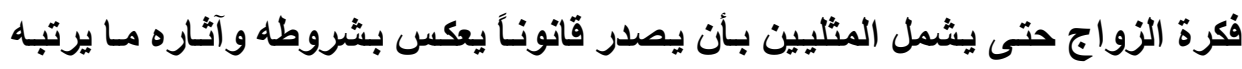

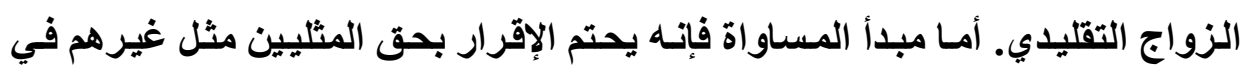

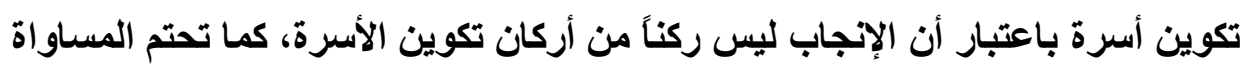

Gallmeister, note H. Fulchiron ; ibid. 1056, obs. H. Gaudemet-Tallon et F. Jault-Seseke ; ibid. 1408, obs. J.-J. Lemouland et D. Vigneau ; AJ fam. 2015. 172, obs. A. Boiché ; ibid. 71, point de vue B. Haftel ; RTD civ. 2015. 91, obs. P. Puig ; ibid. 343, obs. L. Usunier ; ibid. 359, obs. J. Hause, Revue critique de droit international privé 2015, p. 400.

(1) Arrêt 121/2010 du 8 avril 201013 mars 2010: Hubert Alcaraz, Le mariage entre personnes de même sexe dans la jurisprudence constitutionnelle étrangère, RFDA 2013.

(2) Hubert Alcaraz, Le mariage entre personnes de mêmeł sexe dans la jurisprudence constitutionnelle étrangère, RFDA 2013 p.986. 
ترتيب نفس الثروط والآثار على زواج المثليين مثلهم في ذلك مثل الزواج بين الرجل

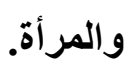

وقضت المحكمة العليـا للولايـات المتحدة بـأن منع الترخيص بزواج المثليين يخالف التعديل الرابع عثر في المساواة وفي الدعوى العادلة ('). وأصبح من حق من التحان يتزوج من المثليين أن يستفيد من قوانين الهجرة مثله في ذلكت مثل المتزوجين بعقد

معتاد منذ حكم United States v. Windsor (") وحكم Re Zeleniak ("). وقد طرح الأمر على المحكمة الاستورية العليا للولايـات المتحدة الأمريكية في قضية تعلقت بإحدى السيدات في ولاية نيويورك كانت متزوجة أنثى مثلها ولمسا توفيت

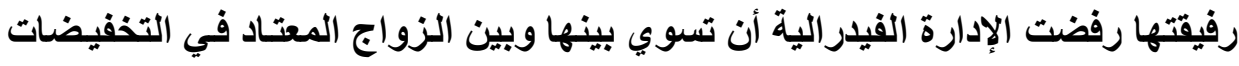
الضريبية على التركات. طعنت السيدة Windsor في قرار الإدارة ووصل الأمر إلى لهى

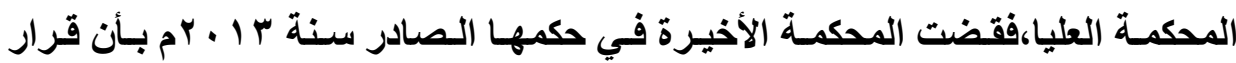
الإدارة يخالف التعديل الخامس من الاستور الأمريكي حيث يخالف مبدأ المساواة(').

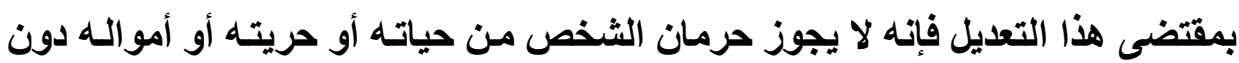

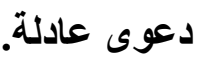

(1) United States Supreme Court Obergefell v. Hodges, 135 S. Ct 2584, 2600-08 (2015).

(2) United States Supreme Court: united states v. Windsor, 133 S. Ct. 2675 (2013).

(3) United States Supreme Court: re Zeleniak, 26 I. \& N. 158, 158 (B.I.A. 2013)

(4) United States v. Windsor, 570 U.S. (2013; United States v. Windsor, U.S. District Court of the Southern District of New York, 6 juin 2012, 833 F. Supp. 2d 394 (S.D.N.Y. 2012); United States v. Windsor, U.S. Court of Appeals, $2^{\text {d }}$ Circuit, 18 oct. 2012. 
وأصدرت المحكمة العليا المكسيكية برتوكولاً في 11 أغسطس ؛ 1 ـ ب م، يهدف إلى مساعدة القضاة في اتخاذ القرارات المتعلقة بالتوجه الجنسي والهوية الجنسية وفقاً لحقوق الإنسـان، لاسـيما مـا يتعلق منهـا بالقضاء على المفــاهيم المسبقة المفسرة اجتماعياً فيما يرتبط بخصائص وسـلوكيات أو سـات الأثخاص المثليين من عمليـات صنع القرار. فيدعو هذا البرتوكول القضاة إلى التشكيك في حياد القانون المطبق على

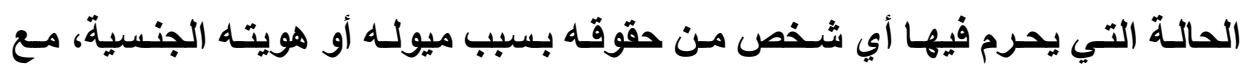
ضرورة تقييم الأدلة دون استخدام القوالب النمطية المتعلقة بالميل الجنسي أو الهويـة

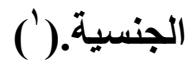

\section{ثانيًا: هوقف المكمة الأوربية لهقوق الإنسان هن زواج المثليين}

في قضية Parry و R. et F وفي بريطانيا تحول كل من السابق ذكرهما من الأكورة إلى الأنوثة وطلبا الاعتراف باستمرار زواجهمـا من الناحية القانونية حتى لا لأل يحدث الطلاق. رفضت المحاكم الأنجليزية طلبهما فلجأ كل منهمـا إلى المحكمـة الأوربية لحقوق الانسان مستندين إلى المادة (r I ) من الاتفاقية. رفضت المحكمة طلبهما مؤكدة

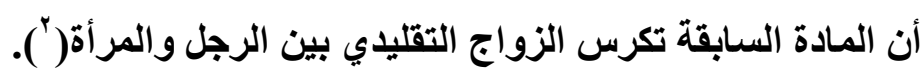
كمـا وقد تعرضـ المحكمة الأوربية لحقوق الإنسان لمسألة زواج المتحولين I. et Christine Goodwin c/ Royaume- فنسياً قضية transseuel ولـم تعترض عليه. وقد استتدت المحكمة إلى المـادة (9) من ميثـث الحقوق

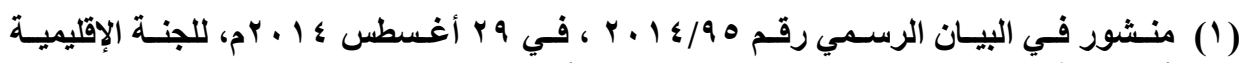

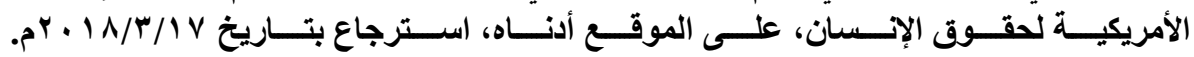
.http://www.oas.org/en/iachr/media_center/PReleases/2014/095.asp

(2) Jean-Pierre Marguénaud, op.cit 
الأساسية للاتحاد الأوربي والتي تقرر الحق في تكوين أسرة لكل شخص ولم تتحدث

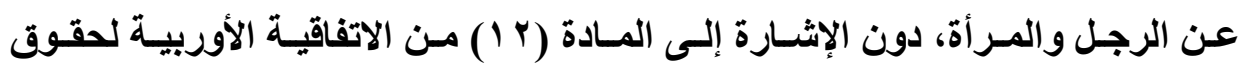
الإنسان والتي ذكرت الرجل والمرأة(').

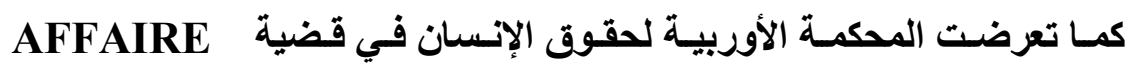
TADDEUCCI ET Mc CALL c. ITALIE

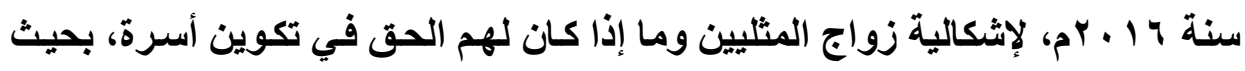
تسمح لأحد أطراف تلك الأسرة أن يحصل على الإقامة في بلا أوربي مع رفيقه ألأوربي

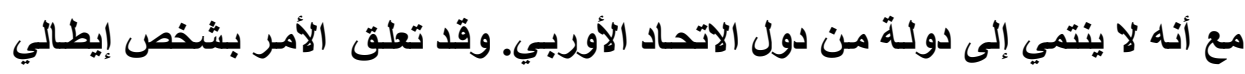

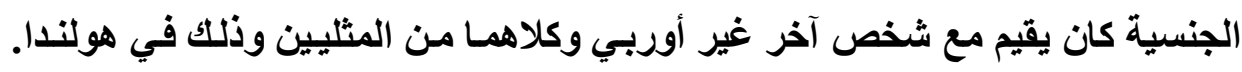

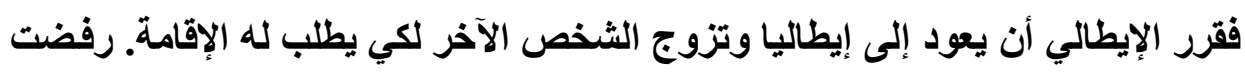

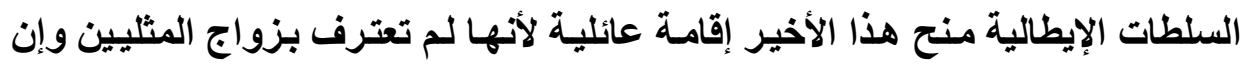

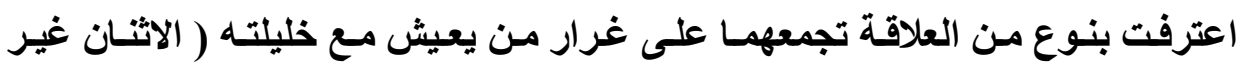

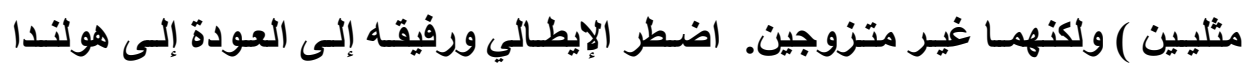

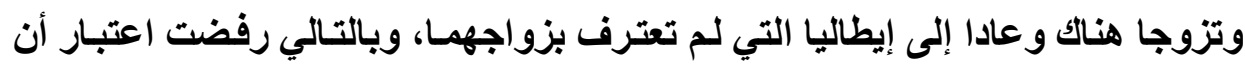

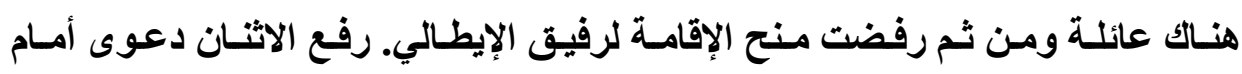

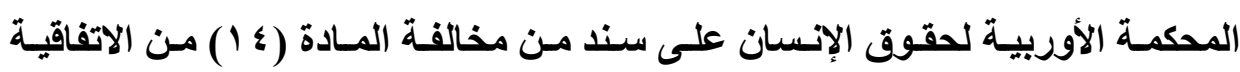
الأوروبية لحقوق الانسان التي تنص على عدم التمييز في التمتع بالحقوق التي تقررها

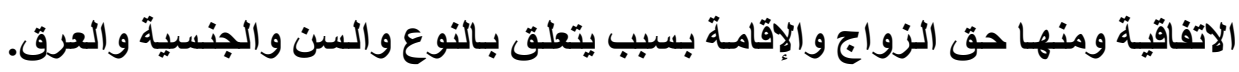
وكان الطعن مبنـاه أن إيطاليا تقيم التمييز ضدهما بسبب توجه كل منهمـا نحو الآخر

(1) European Court of Human Rights: I. et Christine Goodwin c/ Royaume-Uni du 11 juillet 2002. 
(المثلية) وأن هذا بخالف مبأ علم التمييز؛ ذلك أن المادة ( ( ) من الاتفاقية الأوروبية

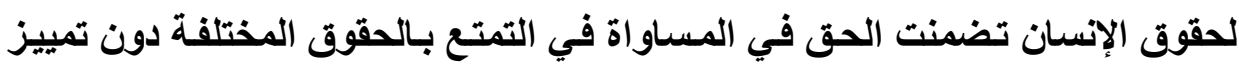
بسبب السن أو النوع أوالدين أوالعرق.

صحيح أن المـادة (^) من تلكك الاتفاقية عندما تقرر الحق في حرمسة الحياة

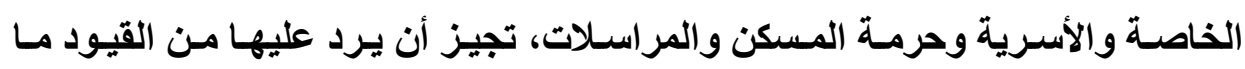

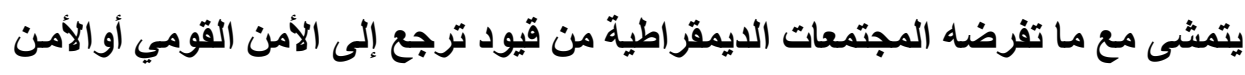

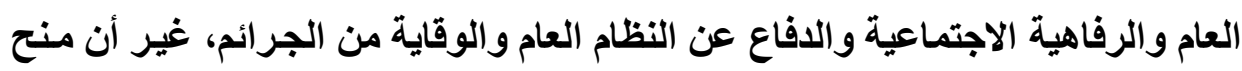
زواج المثليين لا يبرره أي من الاعتبارات السابقة.

وقد دافعت الحكومة الإيطالية عن موقفها بأنه لا ينطوي على تمييز، حيث أنها

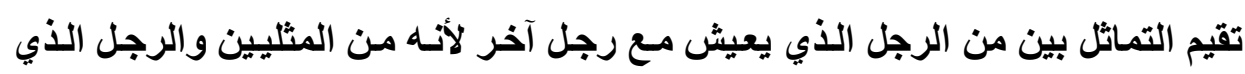

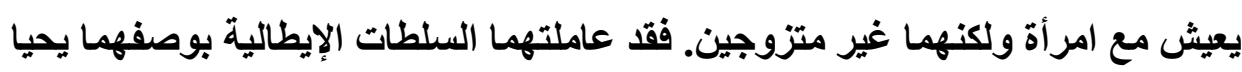

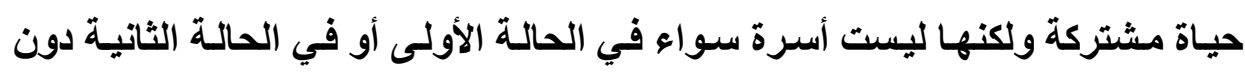
تمييز.

وقضت المحكمة الأوربية لحقوق الانسان في تلك القضية ـ بأن الاثنين عندما

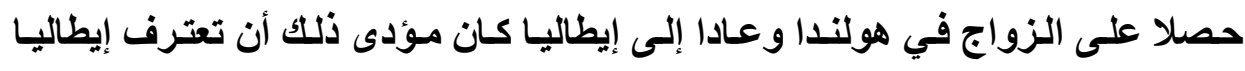

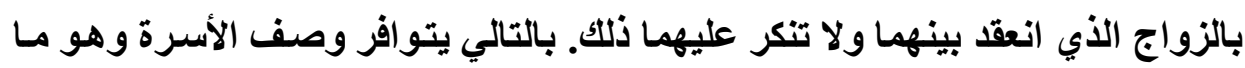

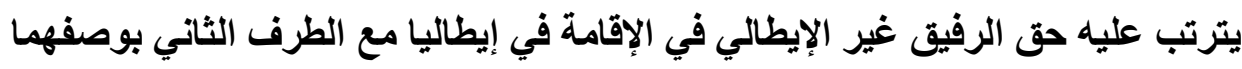

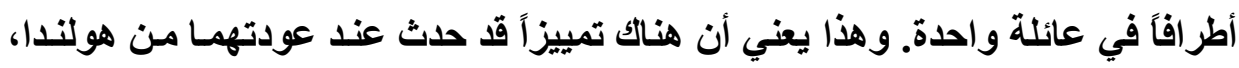
ولم تعد تتوافر المساواة بين المثليين وبين غير المثليين اللذين لم يجمعهمـا عقد الزواج، حيث أن هناك واقعة جديدة وهي الزواج بين المثليين. أمسا غير المثليين فهما 
يملكان أن يتزوجـا في إيطاليـا ولم يكن ذلكت متاحساً للمثليين، وبالتـالي فهنـاك تمييزاً ضدهما بسبب المثلية التي تجمع بينهما وهو ما لا يجوز. ويناء عليه قضت المحكمة في هذه القضية بأن إيطاليا خالفت المـادة (ع () من

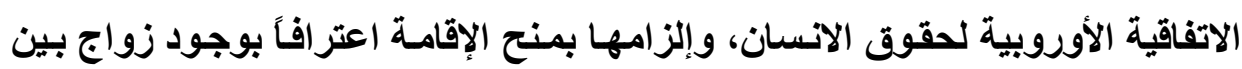

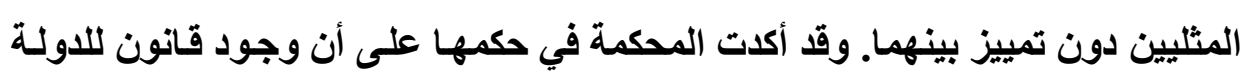

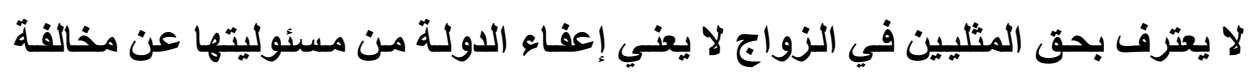
الاتفاقية الأوربية لحقوق الانسان غير المثليين.(')

كمـا لاحظت المحكمـة أن هنـاكك مـن الدول عدداً متزايداً نحو الاعتراف بحق

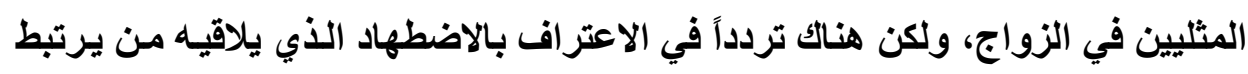

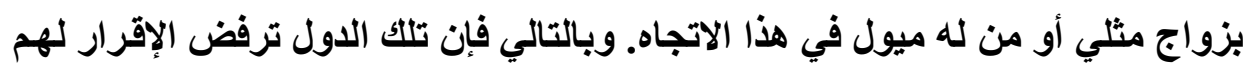

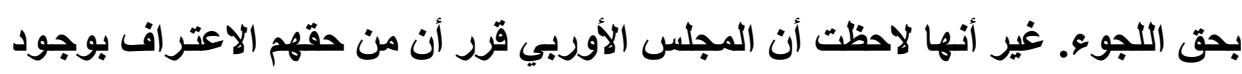

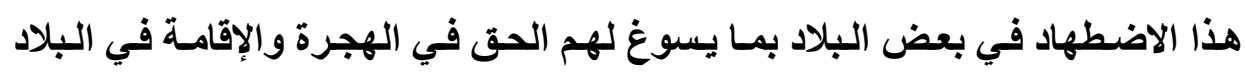

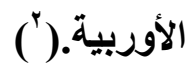

(1) European Court of Human Rights Cour Europeenne des Droits de l'Homme . AFFAIRE TADDEUCCI ET McCALL c. ITALIE, 30 juin 2016. (Requête no 51362/09).

(2) Voir, par exemple et mutatis mutandis, Thlimmenos c. Grèce [GC], no 34369/97, § 48, CEDH 2000-IV). 


\section{المبحث الثالث}

\section{آثار العلاقات المثلية الشاذة على الفرد والجتهمع وطرق هعالجتها}

بعدما تعرضـنا لمفهوم المثليـة الشـاذة أيـاً كانـت دوافعهـا، وموقف شـريعتنا الإسـلامية الغراء وتجريمها لها، فضلاً عن بيـان موقف الدول التي وقفت بين مؤيـا ومعارض، كان لابد من تعميق الوعي بما ينتج عن تللك الممارسات من أضرار وخسائر

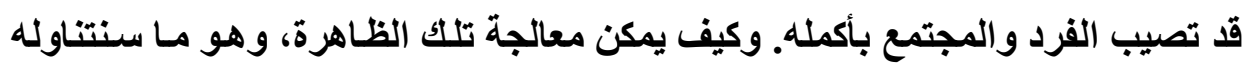

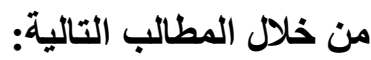

\section{المطلب الأول \\ آثار العلاقات المثلية الشاذة على الفرد والمتتمع \\ (أ) انتهاك الحق في المضن الإنساني الطبيـي}

على الرغم من وجود اتجاهـات مختلفة تؤيــ العلاقـات المثلية وبصفة خاصـة

زواج المثليين بليل موافقة المجلس الأوربي على زواج المثليين وحقهم في تكوين أسرة، حيث أقر البرلمان الأوروبي زواج المثليين في قراره الصادر في ب أبريل سنة

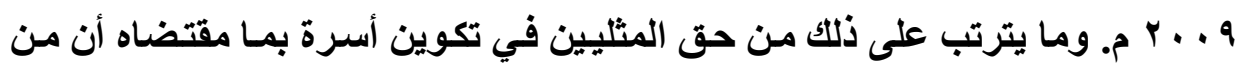
حق كل طرف أن يقيم مع الطرف الثاني في تلك الأسرة مـادام الأول من رعايـا الاتحساد

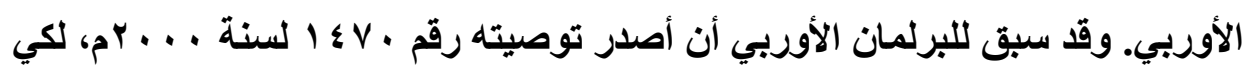


يوجه الدول الأوروبية الأعضاء بالاعتراف بعدم التمييز ضد من تجمعهم اتجاهات مثلية

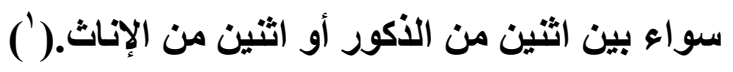

إلا أن ذلك يعد انتهاكاً لحقاً أساسياً للفرد وهو حقه في المحضن الطبيعي وهي

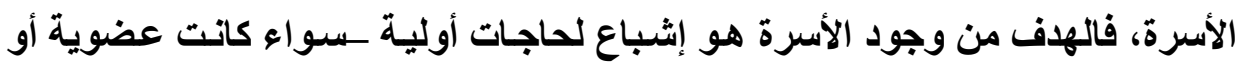

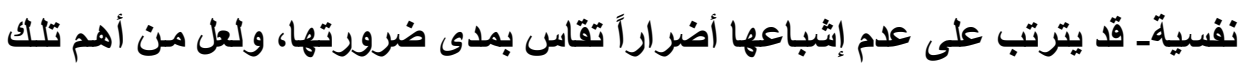

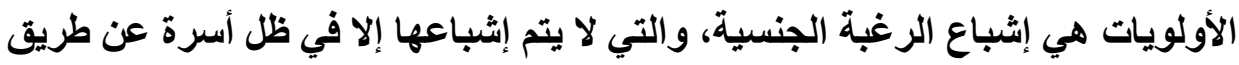

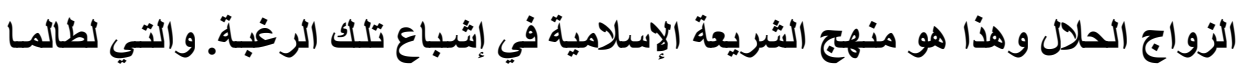
تحمي المجتمع من الوقوع في شر العلاقات المثلية الثشاذة. وقد نصت دسـاتير الدول والمواثيق الدولية على الحق في تكوين الأسرة ونششأة الطفل في محضنه الطبيعي، وأكلـت على أن الأسـرة هـي الوحلـة الطبيعيـة الأساسية في المجتمع.(") ويعد من بين المبادئ التي تضمنها إعلان حقوق الطفل لعام الطيام

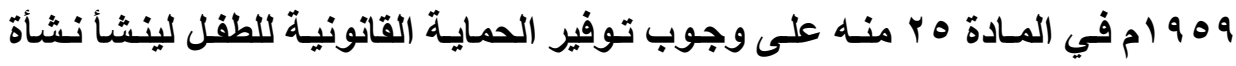
طبيعة، وهذا يعني أن يكون لكل طفل الحق في التمتع بعناية خاصة في ظل تنشئة سليمة من الناحية البدنية والروحية والاجتماعية، ولا يحدث ذلك إلا في محضنه وبيئته

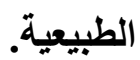

فالأسرة لها أهداف لابد من تحقيقها في ظل التزامها بالمنهج الأخلاقي والديني، وقد حثنا دينتا الحنيف على تكوين الأسرة، باعتباره حصناً للزوجين من الوقوع في فلالهي

(1) Recommandation 1236 (1994) relative au droit d'asile et de sa Recommandation 1327 (1997) relative à la protection et au renforcement des droits de l'homme des réfugiés et des demandeurs d'asile en Europe.

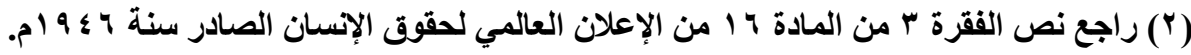


الفواحش و الفوضى الجنسية، فقال رسول الله صلي الله عليه وسلم " النَّكَحُحُ مِنْ سُنَّتَّي

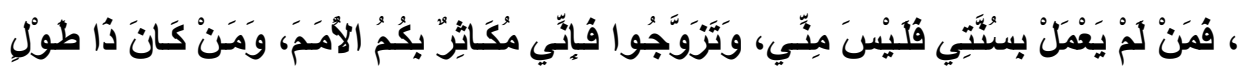

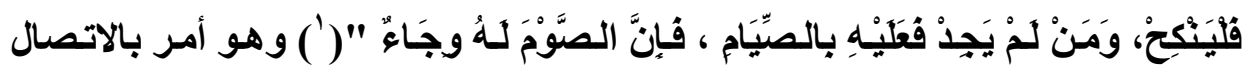
الحلال عن طريق الزواج الثرعي لإثباع الميول الجنسية دون انحراف.

ويختلف الاور الذي يلعبه كل من الأبوين، فالطبيعة لا تنثأ جنسين ليكون لهمـا

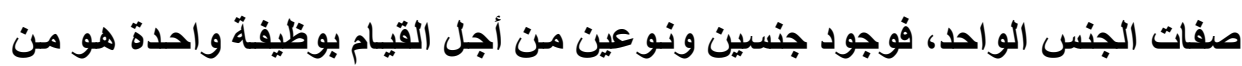

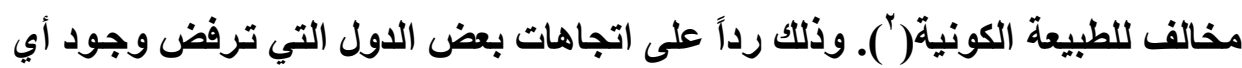

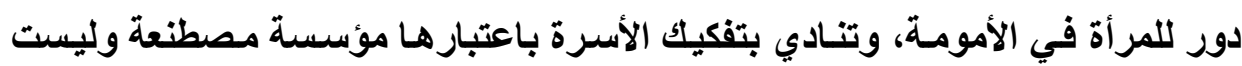
طبيعية، بل وتعتبر أن قيم العفة والأمومة معوقات صنعت لتزييف فكر المرأة و إنكار

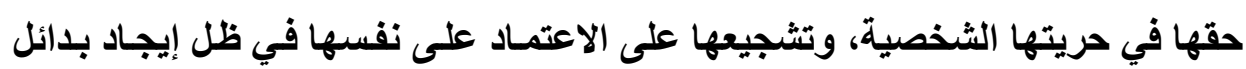
كاباحة الثذوذ و التلقيح الصناعي.(")

وتطلبت الحياة الأسرية وجود النوعين المختلفين، لتباين صفاتهم والاعتراف بالمسئولية المشتركة لكل من الرجل والمرأة في تنشئة أطفالهم، فلالمرأة تتميز باللين و العطف والحنان، بينما اختص الرجل بالقوة والصلابة، ولا غنى عن كل تلكت الصفات

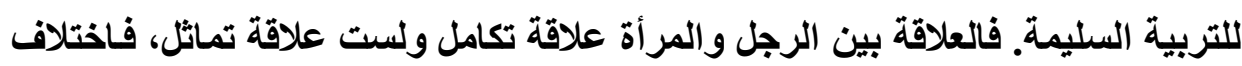
صفات الرجل عن المرأة لمصلحة كليهما، لاسيما المرأة وأن لها أنماطاً سلوكية تمثل

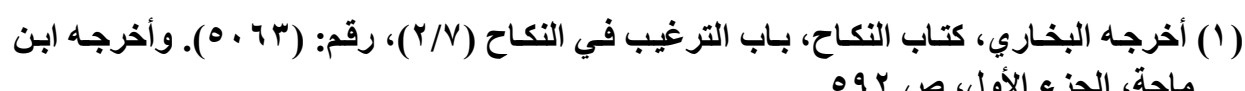

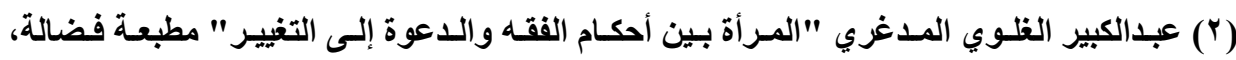

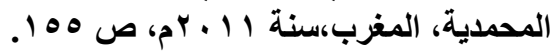
(r) عو اطف عبدالماجد إبراهيم "موقف الإسلام من اتفاقية القضاء على جميع أثنكال التمييز ضد

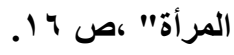


الاور المطلوب منها كامرأة وأم وزوجة، وهو مـا يتوقعه منها المجتمع. فكيف يعيش

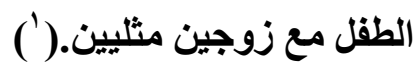
(ب) انتهاك العلاقات المثلية الشاذة لهفظ السلالة البشرية خلق الله الإسـان ودعـا إلى حفظ النسل واستـمراريته عن طريـق الزواج

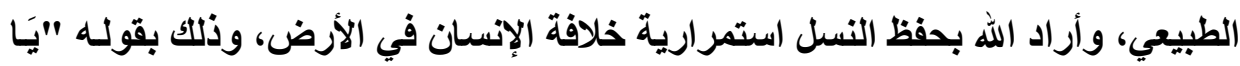

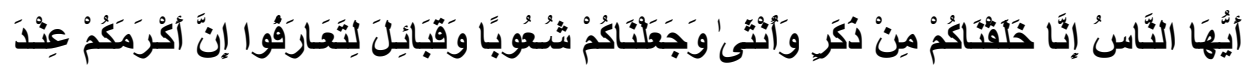

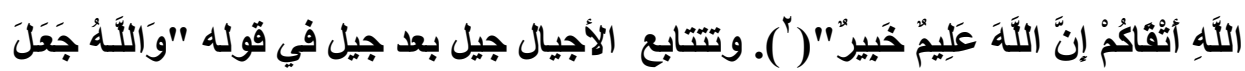

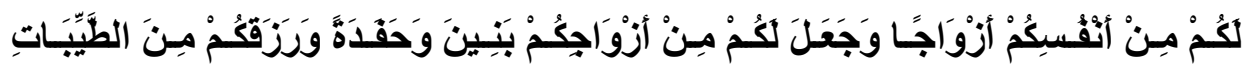

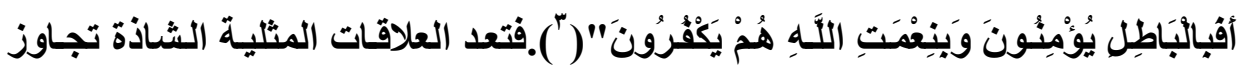

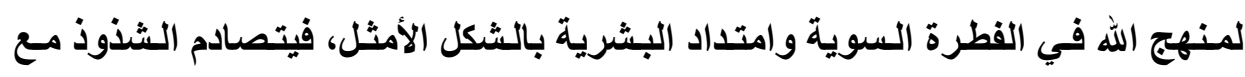

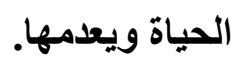

واتجه رأي إلى القول بأن أسباب انهيار الأسرة وابتعاد أطراف العلاقة الأصلية

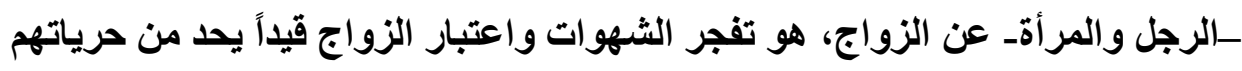

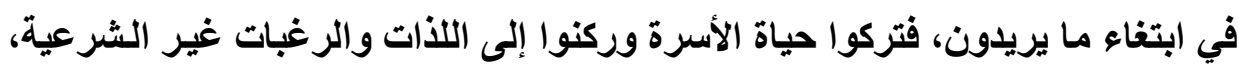
فكلما فترت رغبة أحد الطرفين في الآخر كلما اتجهت إرادة كل منهم نحو البحث عن لذاءة الذاء

(1) نهمى عدنان القاطرجي "المر أة في منظومة الامم المتحدة- روئة إسلامية" الطبعة الثانية، دار إي

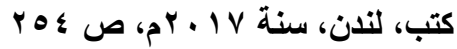

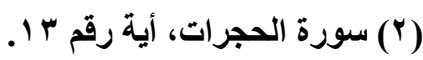

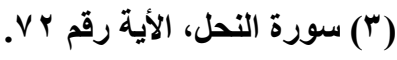


ورغبة جديدة، قد تكون من نفس جنسه؛ وهو ما يؤدي إلى قلة النسل وضعف مقومـات

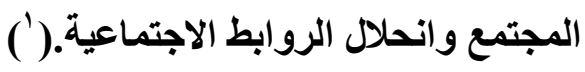

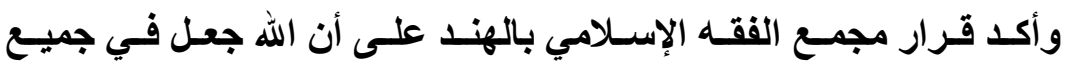

الحيوانات عواطف جنسية لإيجاد النسل، ومن جملتها الإنسان، ولكنه أعطي الإنسان الثرف الخاص في هذا الباب وهو الستر والعفاف، والغزيرة الجنسية التي توجد للاى

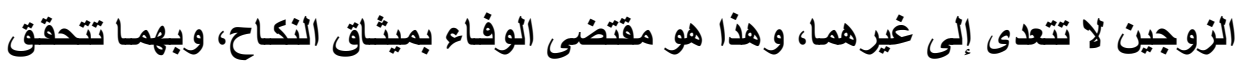

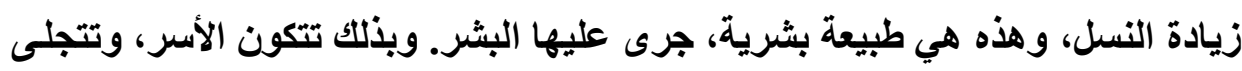
هويـة الأبوين والأولاد، وتتعين الحقوق والواجبات المتبادلة، والحيوانـات الأخرى لا لا

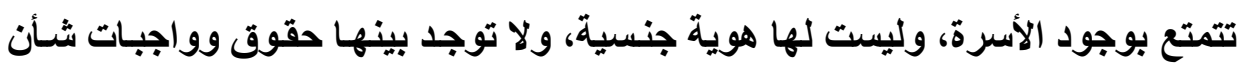

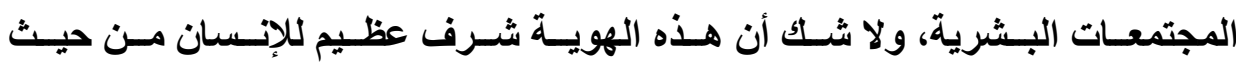

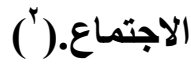

\section{اضطراب نظام التبني}

ترفض الشريعة الإسلامية نظام التبني، وحرصت على أن يكون الطفل نتاج

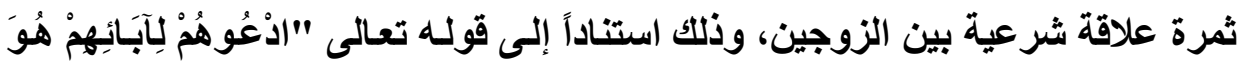

(1) محمد بر هـام المشاعلي "اغتيـال البراءة بيعاً، اغتصاباً، ضرباً" المركز القومي للإصدرات

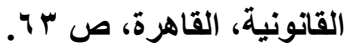

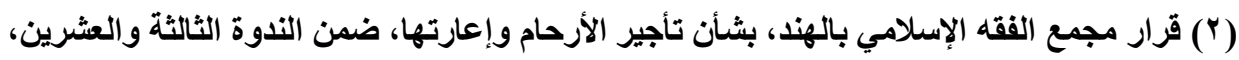

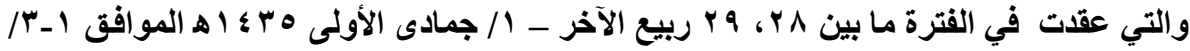

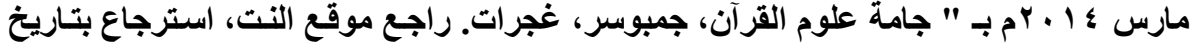
http://www.ifa-india.org 


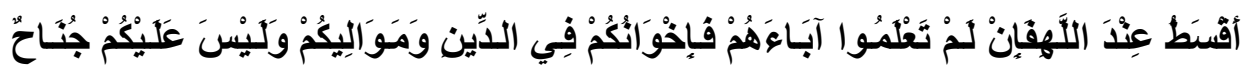

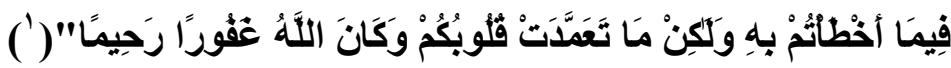

وميع ذلك فبإن تشريعات القانون الوضسعي تسمح بالتبني. وقد ظهرت مشكلة قانونية تتعلق بالتبني عندما يطلب أحد الزوجين المثليين أو كلاهما تبني أحد الأطفال.

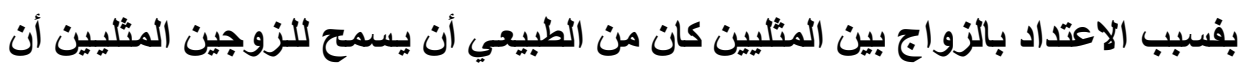

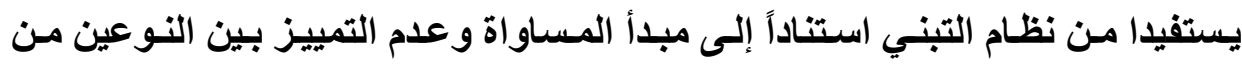

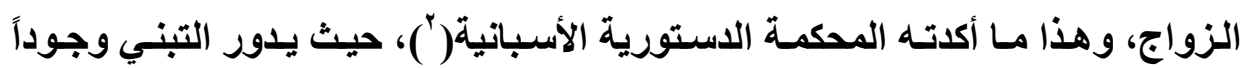

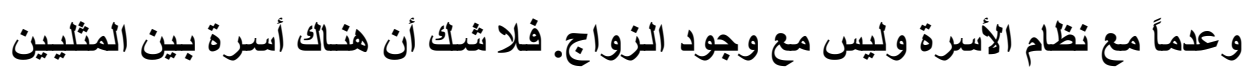

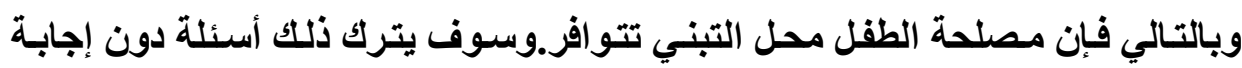
تتمثل في مناقثة مدى توافر مصلحة الطقل في الحياة مع زوجين مثليين . تمزيق الروابط العائلية والاجتماعية

لعل الهـف الأسسى من تكوين الأسرة هو تكوين مجتمع مترابط، حتى ولو

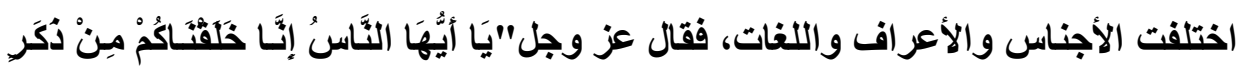

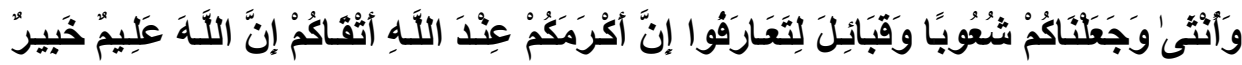

ويؤدي الانحرافعن الفطرة الطبيعية في المجتمع، واستغناء كل جنس عن جنسه

الآخر، وانصراف الثباب عن الزواج، وبعدهم عن قيم وفضيلة المجتمع، إلى ضعف

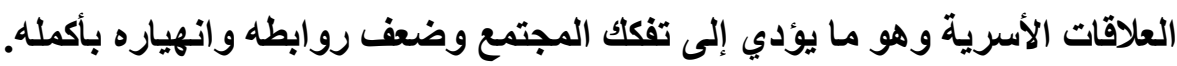

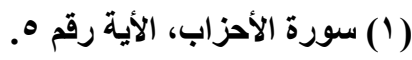
(2) Arrêt 121/2010 du 8 avril 2010, 13 mars 2010.

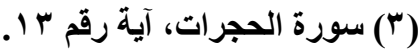




\section{(و) تفشي الأهراض البدنية والنفسية}

تعتبر الأمراض الجنسيه من أثد الأمراض التي تصيب الانسان، ويترتب على العلاقات الجنسية الشاذة والتي تخالف طبيعة الحياة، العديد من الأمراض والتي من التصن

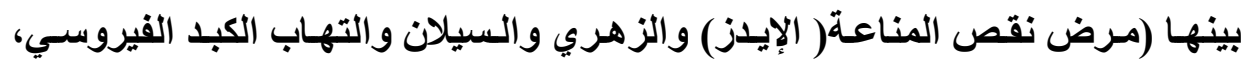
القرحة التناسلية، الابيلة الأربية، التورم الصفني، التهاب الملتحمة الوليدي، التعقيبة،

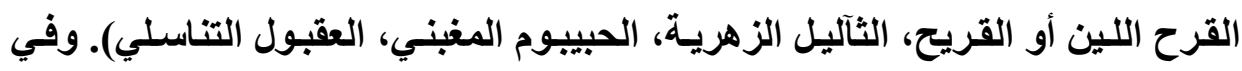
بعض الحالات قد يصاب الثخص بعقم نتيجة تلك الممارسات، بل وقد لا يستطيع القدرة على التحم فيعملية الإخراج لتلف عضلات المستقيم. فضلاً عن الأمراض النفسية التي تصيب الشـاذ كعدم الثُّة بـالنفس والاكتئـاب

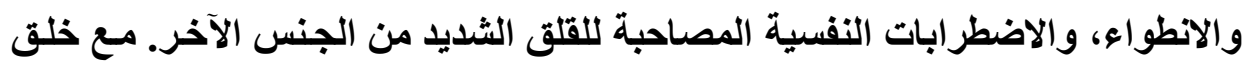
حالة تكمن في نفس المثلي مـا بين المرغوب و المحظور لعلمـه التـام بأن مـا يمارسـه

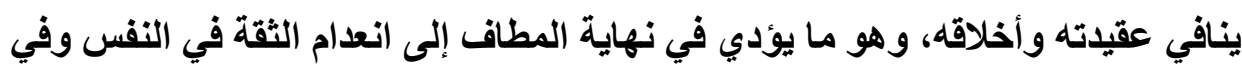
الآخرين، وقد يؤثر سلباً على الثخص المتزوج بصفة خاصة في عدم قدرته على إقامة فئة

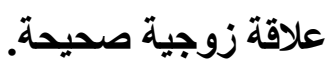

\section{المطاب الثاني}

\section{هعالجات للهد هن ظاهرة المثلية الشاذة}

تتعدد الأدوار التي لا نستطيع القول بأنها سوف تقضي على تلك الظاهرة، بينما

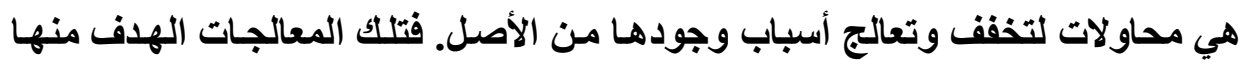

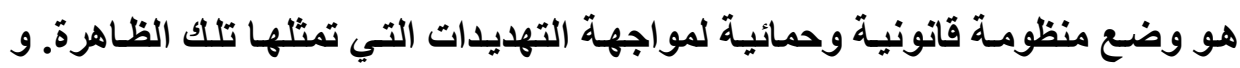
تختلف مابين دور الأسرة ودور وسائل الإعلام ودور الحكومات، وهو ما سنتناوله على النى

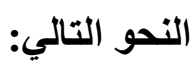




\section{أولاً: دور الأسرة في الحد هن تلك الظاهرة}

الأسـرة هـي النـواه التـي ينشأ فيـهـ الفـرد، فهي عبـارة عـن خليط مسن القيم

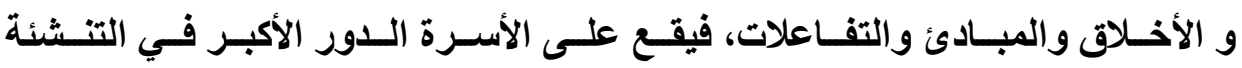

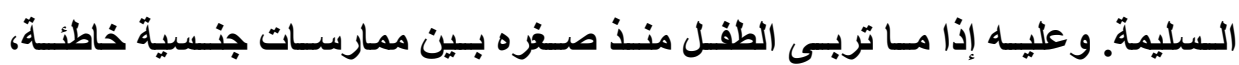

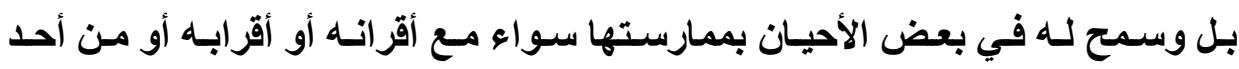
والديسه، فمثل هذه الممارسـات تجعل الطفل أكثر عرضـة مـن غيره في نمـو الميول الجنسية المثلية لايه.

وإذا مـاوقع هذا الطفل فريسة لمن هم من بنـي جنسه، فسوف تقوى ميولهه المثلية وتنمو وتترعرع لايه في الكبر، خاصة وأن اللأة الجنسية تخلق اعتيـاداً وإدمانـاً للجنس بالصورة التي تمت بها ممارسـة تلك الأفعال، خاصـة وإذا تمت بدون عنف أو قهر. فضلاً عن عدم تقبل الطقل لهويته ومساره الطبيعي.(') وقد ورد في المسادة الرابعة والثلاثين من اتفاقية حقوق الطفل، الصادرة عن

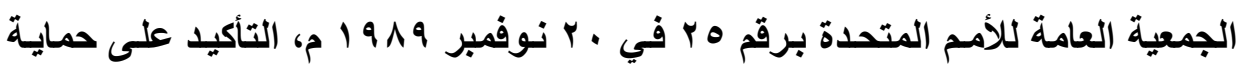
الطفل بصفة خاصة منذ تنشئته، وبصفة خاصـة حمايته من الاستغلال الجنسي بقولها "تتعهد الدول الأطراف بحمايـة الطفل من جميع أشكال الاستغلال الجنسي والانتهاك الجنسي. ولهذه الأغراض تتخذ الدول الأطراف، بوجـه خاص، جميع التدابير الملائمسة الوطنية والثائية والمتعددة الأطراف لمنع: 


$$
\text { (أ) حمل أو إكراه الطقل على تعاطى أي نثاط جنسي غير مشروع. }
$$

(ب) الاستخدام الاستغلالي للاطفال في الاعارة أو غيرها من الممارسات الجنسية

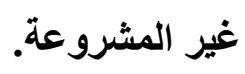

(ج) الاستخدام الاستغلالي للأطفال في العروض والمواد الداعرة.

وعليه فمن الأولى أن يتربى الفرد منذ وجوده داخل الأسرة على الالتزام بتعاليم

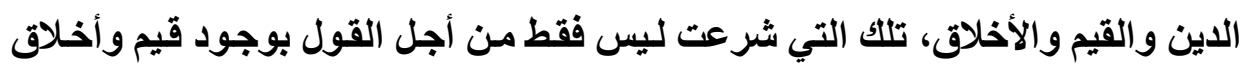

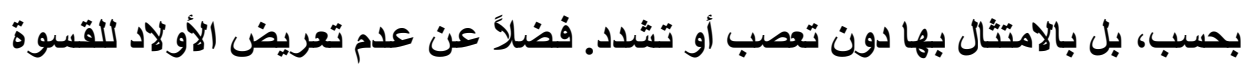

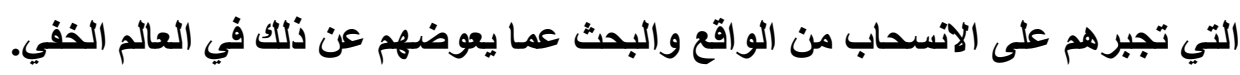
و إلا سوف يعود ذلك على الفرد بآثاراً سلبية لا حد لها.

\section{ثانيًا: دور وسائل الإعلام في الهد من ظاهرة المثلية}

أصبح لوسائل الإعلام حراك قوي في التأثير على أفراد المجتمع - بكافة فئاته ـ

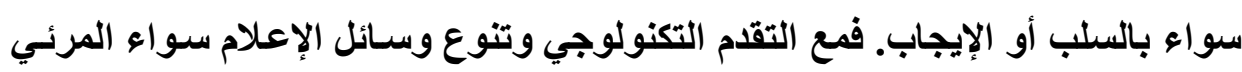

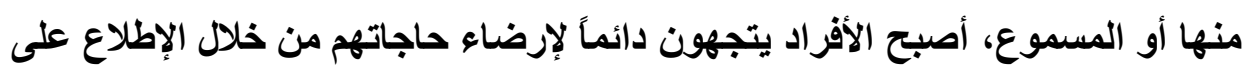

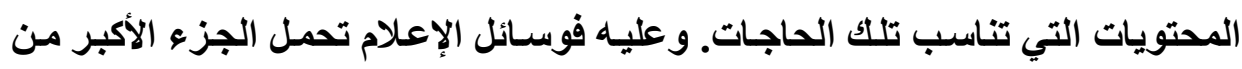
الاتهام بنشر الأعمال الإباحية والمثلية منها خاصة.

فمع كثرة المواقع الإباحية والمصنفات الإعلامية والسماح بنشرها لاسيما على

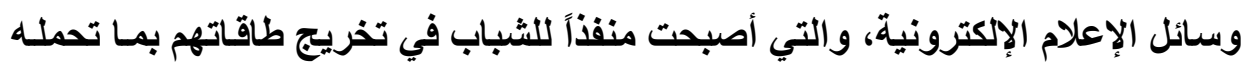

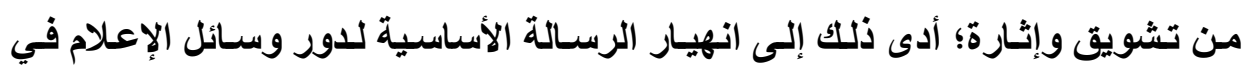

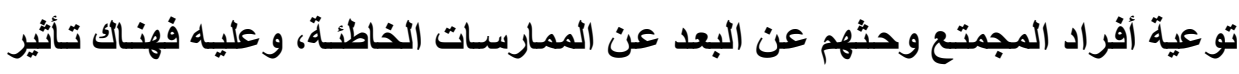
متبادل بين الإعلام وما يرتكبه المثلي من أفعال مخالفة للطبيعة الإنسانية. 
وليس من المغالاة القول بأن وسـائل الإعلام بأنو اعها تحمل مـا قد يثير غرائز الإنسان وبصفة خاصة غرائزه الجنسية، فيلجاً إلى التقليد أو ممارسة المثلية الشاذية

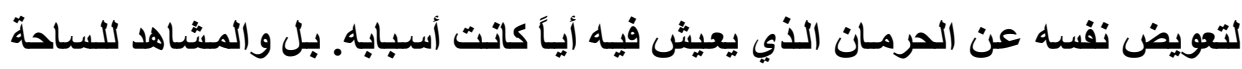
الإعلامية في الوقت الحاضر، أصبح يعلم أن الإعلام يمارس ذلك عن عمد، من أجل

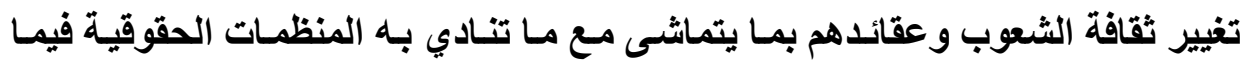
يتعلق بالصحة الإنجابية وحرية الممارسات الجنسية. بناء على ما تقام ولكي يكون للإعلام دور في معالجة تلك الآفة التي أصبحت في

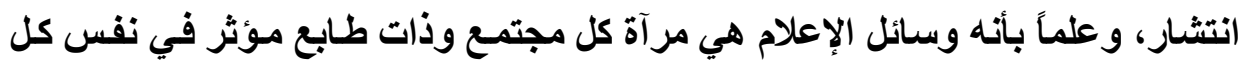

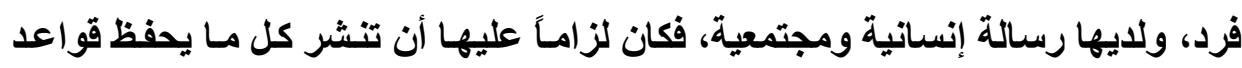

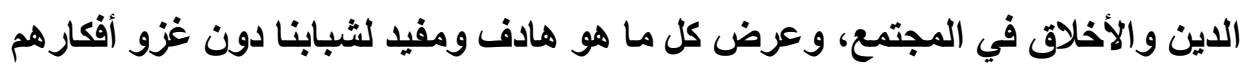
وعقائدهم، في ظل ضو ابطوقيود تحكم العمل الإعلاهي، ومحاريته بشتى الطرق فيما يثيع الفاحشة في المجتمع.

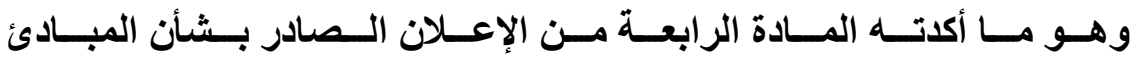

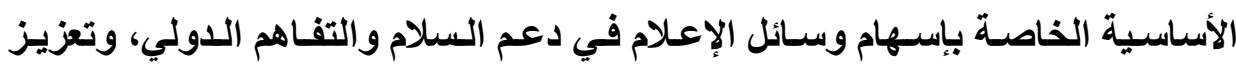

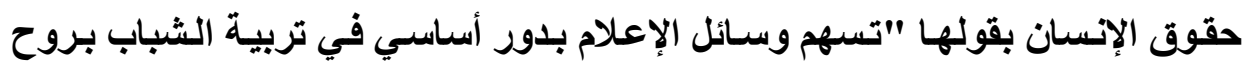
السلام والعدالـة والحريـة والاحترام المتبـادل والتفـاهم، بغيـة تعزيز حقوق الإنسان

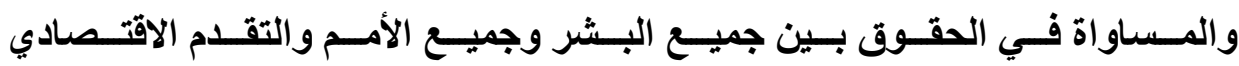

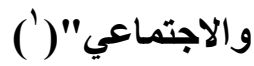




\section{ثالثًا: دور المكومات والمنظهات المقوقية}

يأتي دور الحكومات في مقاومـة العلاقات المثلية والحيلولـة دون تفشيها وذلكك

$$
\text { عن طريق: - من ليقي }
$$

ـ الاهتمام بتدعيم الأخلاقيات الاينية حيث ترفض الأديان كلها العلاقات المثلية ـ التوعية بخطر العلاقات المثلية وذلك بكافة طرق نشر ثُقافات مضادة لهذه الثقافة،

$$
\text { عن طريق المدرسة والمؤسسات الاينية والأسرة. }
$$

ـ تجريم الدعوة إلى العلاقـات المثلية بطريق العلانيـة عن طريق وسـائل العلانيـة

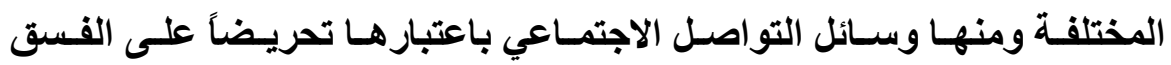

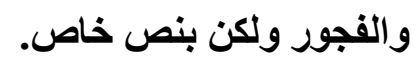




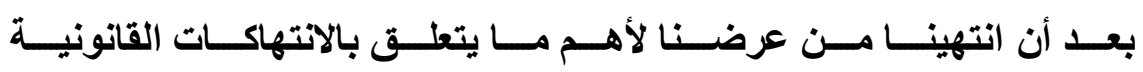

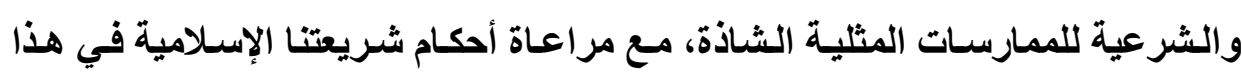

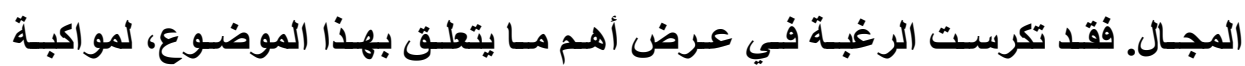
المستحداث التي تطرأ على مجتماعتـا، والتعرف على التكييف القـانوني والشرعي لظاهرة المثليـة الشاذة، وبيـان موقف الدول الذي اختلفت بين مؤيـا ومعـارض لتلك الممارسات. إضافة إلى ما ورد من الأحكام القضائية التي صدرت في هذا الثأن، وأكلت

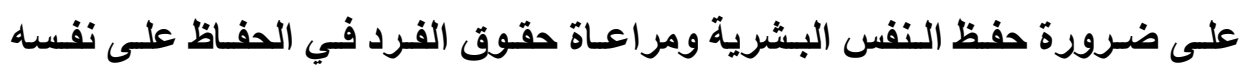
وعرضه. وقد أسفرت الاراسـة إلى عدد من النتائج والتوصيات التي سـوف نتناولها

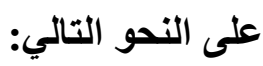

\section{(ألالنتائج)}

اـ الغريزة الجنسية فطرة خلق الله بها الإنسان، وأهم ضرورة إنسانية في حياته، وأحاطها الله بسياج وضوابط لإشباعها بمـا يتفق مـع الشرع ويحفظ استمرار

$$
\text { الحياة والنوع البشري. }
$$

بـالـشذوذ الجنسي مجـرم فـي كافـة التشريعات السسماوية، والمثليـة الجنسية خاصـة كـمط مـن أنماطهـا، وشـددت على عقوبـة مرتكبيهـا أو مسن يروجـون

$$
\text { لها. }
$$

ب-باتـت ظـاهرة المثليـة الشاذة في اتسـاع، متحديـة بـذلك كافـةالأعراف والقيم بـل والقوانين التجريمية، فبعد أن كاتت تلك الظـاهرة في بوتقة ضيقة لا يعلم عنها الكثير، إلا أنها خرجت الآن ليس فقط للمناداة بحقوق أصحابها، بل بمهاجمة كل ما يوجه انتقاداً لها أو يدين أعمالهم الثاذة. 


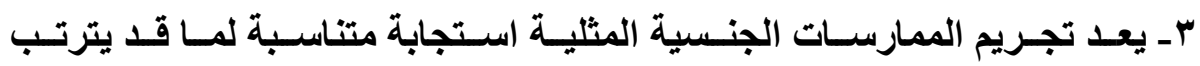

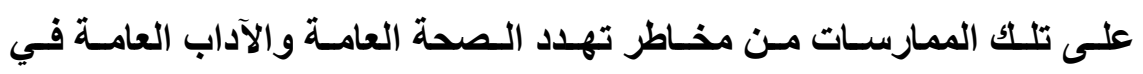
المجتمع. عـ مـن الغريب فـي الأمـر منــاداة الكثير مـن المنظمـات الدوليـة والمجتمـع الـدولي، بإلغاء القوانين التي تجرم العلاقات الجنسية الشاذة القائمسة على التراضسي بين إنـاس من نفس الجنس، والقضاء على غير ذلك مـن القوانين التي تستخدم لمعاقبة الأفراد على أسـاس ميـلهم وهويتهم الجنسية، و والتي تعتبر انتهاكـاً لحقوق الإنسان.

هـ للحكومات الرافضة والمعارضة للمثلية الشاذة دوراً بـارزاً بـل في تحد دائم ضد المروجين لنشر أفكار المثليين والدعوة إلى الاعتراف بممارساتهم.

(ب) التوصيات

ا- نوصي الحكومات باتخاذ كافة الإجراعات الممكنة، في سبيل التصدي لمثل هذه

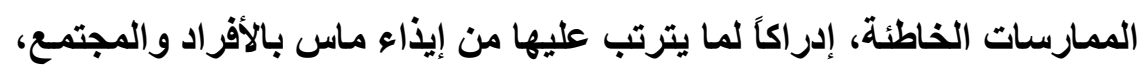
ومن ثم فعليها أن تسارع خطواتها في تشديد تجريم السلوك المثلي، لاسيما

$$
\text { القائم على التزاضي. }
$$

r- على الإعلام الأمثل أن يقوم بتوعيـة أفراد المجتمع حـل أضـرار الممارسـات

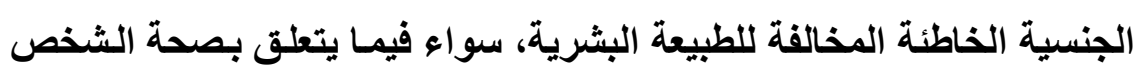
أو نفسه أو علاقاته وروابطه الاجتماعية. r- نوصي التشريعات العقابية بأن توقع تدابير علاجيـة للأشخاص المتورطين في

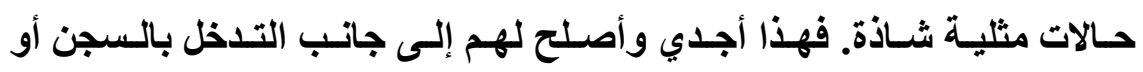
بالغرامة في كثير من الحالات. 
ع- تحديد جهة مختصة لرصد حالات المثلية الجنسية، ووضع آليات بنـاعة قابلة للتحقيـق، ومتابعـة كل الدراســات والبحـوث التـي تحقق حمايـة مثلى للأفر اد المعرضين لتلك الاتحرافات.

هـ مناثــدة جميـع الجهـات المختصة، بعقد دورات تدريبيـة للفئــات ذات العلاقـة والاتــصـال المباثـر مــع الأطفــال، كالمدرسـين والأخــصائيين الاجتمــاعيين بالمدارس، وذلك من أجل الاكتثاف المبكر لحالات الإسـاءة التي قد يتعرضون لها من قبل ذويهم أو أقاربهم.

7ـ التشديد على دور الجهات والمنظمـات الدينيـة، بتوعيـة أفراد المجتمـع بحفظ العرض وعدم المساس بـه بأي شكل غير مشروع ويخـالف الطبيعة الإنسانية التي خلق الله عليها الإنسان. 


\section{قائمة المراجع}

\section{أولاً: القرآن الكريم \\ ثانيًا: الأحاديث النبوية الشريفة}

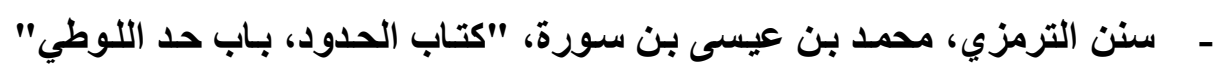

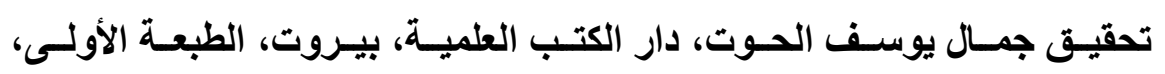

. $9 \wedge \vee$

- صحيح البخاري، أبو عبدالله بن محمد بن اسماعيل البخاري، تحقيق: مصطفى

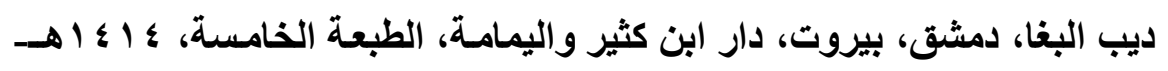

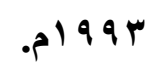

\section{ثالثًا: المعاجم اللغوية}

- القـاموس المحيط، لمجد اللدين يعقوب الفيروز آبـادي:تحقيتق مكتبـة التـراث،

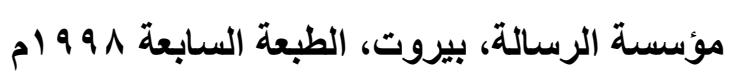

- معجم مقـاييس اللغـة، لأحمــ بن زكريـا ابن فـارس: تحقيق عبدالسلام محمد

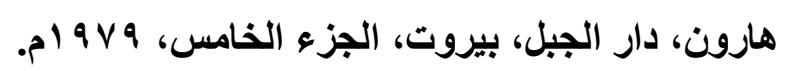
- المعم الوسيط، مجمع اللغة العربية، طبعة المطابع الأميرية، القاهرة، ؟ +. بام.

\section{رابعًا: كتب الفقه الإسلاهي:}

- أبو عبدالله محمد الحطاب "مواهب الجليل على مختصر الخليل" تحقيق زكريا

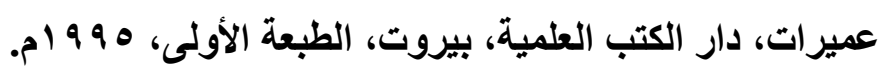


- الحاكم النيسابوري "المستدرك عن الصحيحين" مطبعة النصر، الرياض، الجزء الرابع، بلون سنة نشر.

- علاء الدين أبويكر بن مسعود الكاسـاني "بدائع الصنائع في ترتيب الشرائع"

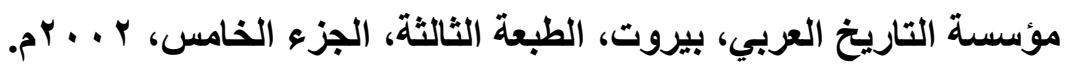
- محمد أحمـد الفتوحي بن عثمـان النجدي "منتهى الإردات في جمـع المقتع مـع

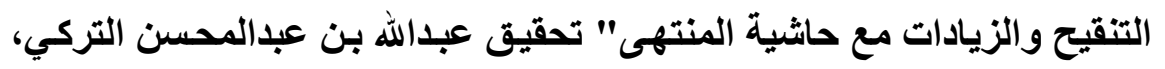

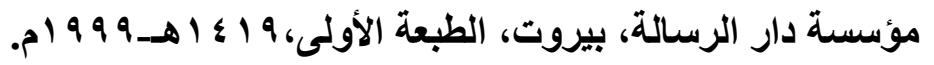

- محمـد الخطيـب الشربيني "مغتـي المحتـاج إلـى معرفـة معساني ألفــاظ المنهـاج" تحقيق علي معوض، دار الكتب العلمية، بيروت، الطبعة الأولى . . . بم.

خامساً: الكتب (أ) (أ) كتب عاهة

- كمال دسوقي " ذخيرة علوم النفس" وكالة الأهرام للتوزيع، ـ9 أم. - محمود عواد "معجم الطب النفسي" دار أسـامة للنشر والتوزيع، عمـان الأردن،

$$
\text { . } 11
$$

- مدحت عبدالرزاق الحجازي "معجم مصطلحات علم النفس" دار الكتب العلمية،

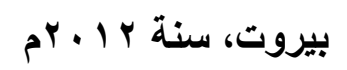

- منير البعلبكي "موسوعة المورد- دائرة معارف انجليزيـة عربية مصورة" دار العلم للملايين، بيروت، الجزء التاسع، بلون دار نشر. 
- إدوارد غالي الذهبي "الجرائم الجنسية وإثباتها" دار النهضة العربية، القاهرة،

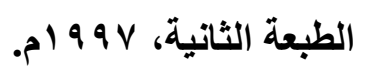

- إغس كـارول، لوكـاس بـاولي إيتـابوراثي "رهـاب المثليـة التـي تمارسـه الدول،

دراسة استقصائية عالمية عن قوانين الدول التي تحمي أو تجرم أو تعترف بحب

المثليـين أو حقـوقهم" منظمـة إيلغــا، الطبعـة العاشـرة، الطبعـة العاشـرة، مسايو

$$
\text { . } 10
$$

- إمام عبدالواحد مرسي "الثذوذ الجنسي وجرائم القتل" دار المعارف، القاهرة،

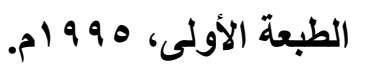

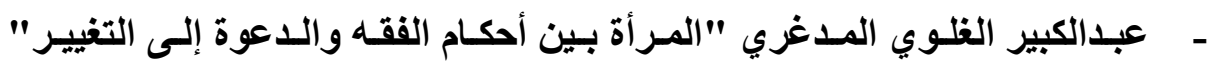

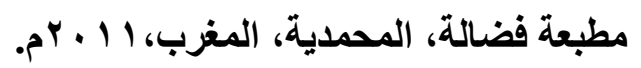

- عواطف عبدالماجد إبراهيم "موقف الإسلام من اتفاقية القضاء على جميع أشكال التمييز ضد المرأة" مركز دراسات المرأة، الخرطوم، بدون سنة نشر. - علـي أبو الحجيلـة "الحمايـة الجزائيـة للعرض في القـانون الوضـعي والشريعة

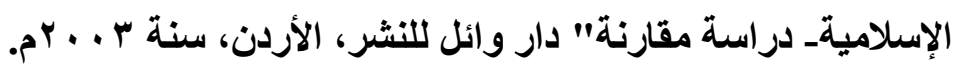
- كولن ويلسون "أصول الدافع الجنسي" ترجمة يوسف شرورو، وسمير كتاب.

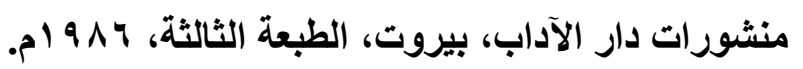
- محد برهام المشـاعلي "اغتيال البراعة بيعـاً، اغتصاباً، ضرباً" المركز القومي للإصدرات القانونية، القاهرة، بدون سنة نشر. 


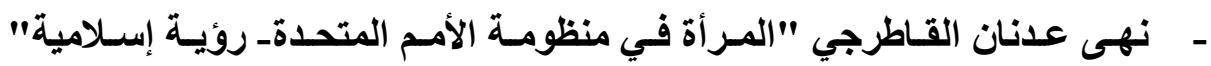

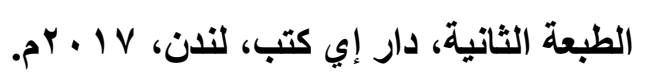

- هند عقيل الميرز "الجنسية المثليةـ العوامل والآثار " مجلة دراسـات في الخدمة الاجتمـاعيـة والعلـوم الإنسـاتية، جامعـة حلـوان، العـد الرابـع والثلاثتون، إبريـل

$$
\text { مr. Ir }
$$

\section{سادساً: القوانين والأنظمة}

- ق قانون العقوبات الكويتي رقم 19 لسنة ـ 9 ام.

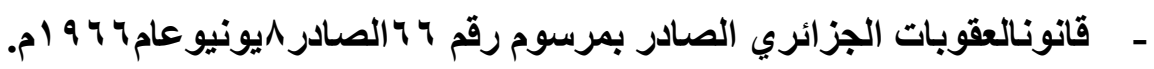

-

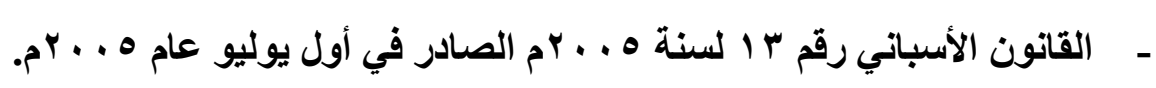

- نسوص قـانون العقوبـات المـصري المعدلــة بمرسـوم بقـانون رقـم 11 لسـنة

$$
\text { . } 11 / 0 / Y \leq
$$

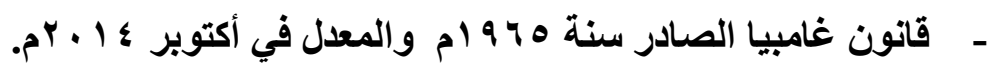

\section{سابعًا: هجموعة الأهكام القضائية}

- مجموعة أحكام النقض المصرية

- مجموعة الأحكام القضائية السعودية، المملكة العربية السعودية، وزارة العدل،

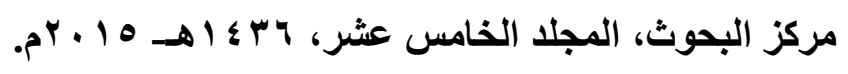

ثاهنًا: قراراتوهمؤتمرات وهماثيق دواثية

- الإعلان العالمي لحقوق الإنسان الصادر سنة 7 ـ 9 ام. 
- الإعلان الصادر بشأن المبادئ الأساسية الخاصة بإسهام وسائل الإعلام في دعم

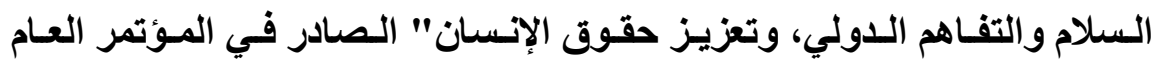

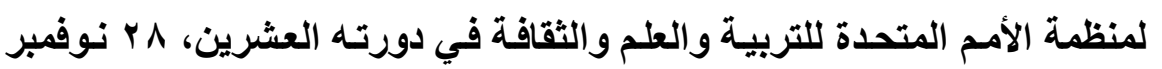

$$
\text { م) }
$$

- اتفاقية حقوق الطفل، الصادرة عن الجمعية العامـة للأمم المتحدة برقم هب في

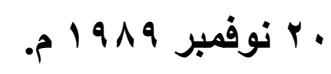

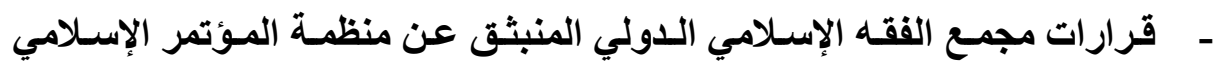

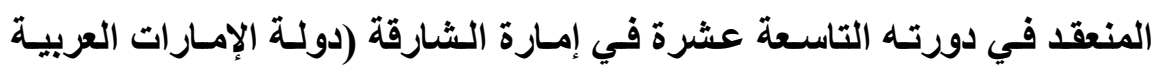

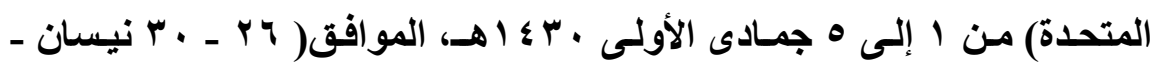

$$
\text { (إبريل9 +. - Tم). }
$$

- قرار مجمع الفقه الإسلامي بالهند، بشأن تأجير الأرحام وإعارتها، ضمن الندوة

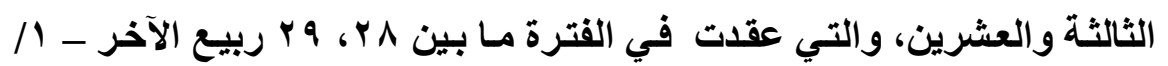

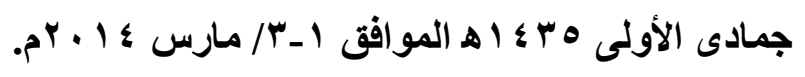

\section{تاسعًا: المواقع الإلكتزونية}

http://www.ifa-india.org -

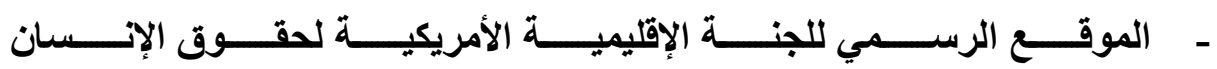

\section{http://www.oas.org}

/http://www.cc.gov.eg الموقع الرسمي لمحمة النقض المصرية http://fatwa.islamweb.net - 


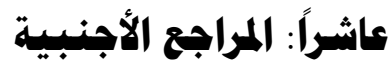

- Ouvrages:

- Didier Boden, Sylvain Bollée, Bernard Haftel, Petra Hammje, Pascal de Vareilles-Sommières, Mariager de personnes de mêmer sexe»: exception d'ordre public: Civ. ${ }^{\text {re }}, 28$ janv. 2015, $\mathrm{n}^{\circ} 13-50.059$, D. 2015. 464, obs. I. Gallmeister, note H. Fulchiron.

- J. Flauss-Diem, Le civil partnership en droit anglais, in J. Flauss-Diem et G. Fauré (dir.), Du PACS aux nouvelles conjugalités : où en est l'Europe ?, Puf, 2005.

- Hubert Alcaraz, Le mariage entre personnes de même» sexe dans la jurisprudence constitutionnelle étrangère, RFDA 2013.

- Décisions judiciaire;

- Cour constitutionnelle d'Espagne06-11-2012, $\mathbf{n}^{\circ}$ 198/2012, Mariage entre personnes de même sexe : validation de la loi espagnole, Recueil Dalloz 2012

- Cons. const., 17 mai 2013, ${ }^{\circ}$ 2013-669 DC, Loi ouvrant le mariage aux couples de personnes de même sexe, JORF du 18 mai 2013, p. 8281, D. 2013. 1643, chron. F. Dieu ; AJ 
fam. 2013. 332, étude F. Chénedé ; Constitutions 2013. 166, obs. A.-M. Le Pourhiet.

- Cour de cassation ,28 janvier 2015 - (Civ. $1^{\text {re }}$ ) ; ibid. 1056, obs. H. Gaudemet-Tallon et F. Jault-Seseke ; ibid. 1408, obs. J.-J. Lemouland et D. Vigneau ; AJ fam. 2015. 172, obs. A. Boiché ; ibid. 71, point de vue B. Haftel ; RTD civ. 2015. 91, obs. P. Puig ; ibid. 343, obs. L. Usunier ; ibid. 359, obs. J. Hause, Revue critique de droit international privé 2015.

- Arrêt 121/2010 du 8 avril 201013 mars 2010: Hubert Alcaraz, Le mariage entre personnes de même sexe dans la jurisprudence constitutionnelle étrangère, RFDA 2013.

- United States Supreme Court Obergefell v. Hodges, 135 S. Ct 2584, 2600-08 (2015).

- United States Supreme Court: United States v. Windsor, 133 S. Ct. 2675 (2013).

- United States Supreme Court: re Zeleniak, 26 I. \& N. 158, 158 (B.I.A. 2013).

- United States v. Windsor, 570 U.S. (2013; United States v. Windsor, U.S. District Court of the Southern District of New York, 6 juin 2012, 833 F. Supp. 2d 394 (S.D.N.Y. 
د/ميادة مصطفى محمد المحروقىى

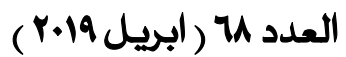

2012); United States v. Windsor, U.S. Court of Appeals, $2^{\mathrm{d}}$ Circuit, 18 oct. 2012.

- European Court of Human Rights: I. et Christine Goodwin c/ Royaume-Uni du 11 juillet 2002.

- European Court of Human Rights Cour Europeenne des Droits de l'Homme - AFFAIRE TADDEUCCI ET McCALL c. ITALIE, 30 juin 2016. (Requête no $51362 / 09)$.

- Thlimmenos c. Grèce [GC], no 34369/97, § 48, CEDH 2000-IV. 